\title{
A Beginner's Guide to Osmoprotection by Biostimulants
}

\author{
David Jiménez-Arias ${ }^{1, * \mathbb{0}}$, Francisco J. García-Machado ${ }^{1,2} \mathbb{0}$, Sarai Morales-Sierra ${ }^{2}$, Ana L. García-García ${ }^{1,2}$, \\ Antonio J. Herrera ${ }^{1}$, Francisco Valdés ${ }^{2}$, Juan C. Luis ${ }^{2}\left(\mathbb{B}\right.$ and Andrés A. Borges ${ }^{1, *} * \mathbb{C}$
}

1 Chemical Plant Defence Activators Group, Department of Agrobiology, IPNA-CSIC, Avda. Astrofísico Francisco Sánchez 3, 38206 La Laguna, Tenerife, Canary Islands, Spain; fjaviergarma@gmail.com (F.J.G.-M.); algg@ipna.csic.es (A.L.G.-G.); ajherrera@ipna.csic.es (A.J.H.)

2 Applied Plant Biology Group (GBVA), Department of Botany,

Ecology and Plant Physiology-Faculty of Pharmacy, Universidad de La Laguna, Avda. Astrofísico Francisco Sánchez s/n, 38071 La Laguna, Tenerife, Canary Islands, Spain; saraimoralessierra@hotmail.com (S.M.-S.); fvaldes@ull.edu.es (F.V.); jcluis@ull.edu.es (J.C.L.)

* Correspondence: david.j.a1983@gmail.com (D.J.-A.); aborges@ipna.csic.es (A.A.B.)

Citation: Jiménez-Arias, D.; García-Machado, F.J.; Morales-Sierra, S.; García-García, A.L.; Herrera, A.J.; Valdés, F.; Luis, J.C.; Borges, A.A. A Beginner's Guide to Osmoprotection by Biostimulants. Plants 2021, 10, 363. https: / / doi.org/10.3390/

plants10020363

Academic Editor: Marcello

Salvatore Lenucci

Received: 20 January 2021

Accepted: 10 February 2021

Published: 13 February 2021

Publisher's Note: MDPI stays neutral with regard to jurisdictional claims in published maps and institutional affiliations.

\begin{abstract}
Water is indispensable for the life of any organism on Earth. Consequently, osmotic stress due to salinity and drought is the greatest threat to crop productivity. Ongoing climate change includes rising temperatures and less precipitation over large areas of the planet. This is leading to increased vulnerability to the drought conditions that habitually threaten food security in many countries. Such a scenario poses a daunting challenge for scientists: the search for innovative solutions to save water and cultivate under water deficit. A search for formulations including biostimulants capable of improving tolerance to this stress is a promising specific approach. This review updates the most recent state of the art in the field.
\end{abstract}

Keywords: osmotic stress; drought; biostimulants; osmoprotectants; salinity

\section{Introduction}

In the next 30 years, world population is expected to increase by 2 billion, reaching 9.7 billion in 2050 [1]. This rate of increase is expected to double during the early 21st century, recently being $25-70 \%$ [2]. That scenario has focused researchers and international organizations on the need to ensure adequate food production, to feed the growing population. A plethora of recent studies have projected situations for the coming years, especially in economically less developed regions such as the Middle East [3] and Latin America [4,5], but also in "rich" countries [6]. Climate change is probably the most important factor endangering agricultural production, especially in Mediterranean and African regions. There, drought periods will almost certainly intensify, yield in more arid zones being intrinsically linked to water availability [7]. Indeed a decrease in productivity due to environmental stress can be forecasted for the upcoming years [8]. Discussion or controversy has arisen in response to this widespread perspective of a need to increased food production to ensure the world's food supply [2]. Its opponents in the debate claim this is not necessary because current global production is sufficient to meet human nutritional needs [9]. Nevertheless, extreme environmental conditions certainly endanger future food security.

Drought and salinity together reduce global crop production by as much as $50 \%$, and their impacts are indeed intensified by climate change [10]. These two factors exert osmotic stress on plants through a drop in soil water potential, due to restricted water availability or solute concentration, respectively (Figure 1).

They cause similar responses, causing water deficit, nutrient imbalance and oxidative stress. The plant responds quickly to this assault by closing its stomata to prevent water loss, which limits gas exchange and consequently photosynthesis and growth [11]. To counteract this, plants need to adjust osmotic balance, this being the main physiological adaptation mechanism they use to cope with osmotic stress. They do this by accumulating 
different kinds of solutes, such as amino acids (especially proline), glycine betaine, and sugars [12]. These osmolytes protect cell structure and function, facilitating water uptake and retention [13]. Since they induce tolerance against osmotic stress [14-16], they are called osmoprotectants [17]. Therefore, the study of these osmolytes and other substances able to induce tolerance [18] is a promising research field. It operates within the search for environmentally friendly treatments to increase food production under stress. Through the upcoming "Farm to Fork" strategy, the European commissioners recommend that EU members work using ecological and sustainable methodologies, reducing fertilizers and pesticides by $30 \%$ and $50 \%$, respectively, by 2030 [19]. In this regard, biostimulants are defined by EU regulation [20] as: "A product that stimulates plant nutrition processes independently of the product's nutrient content, with the sole aim of improving one or more of the following characteristics of the plant or the plant rhizosphere: (a) nutrient use efficiency; (b) tolerance to abiotic stress; (c) quality traits; or (d) availability of confined nutrients in the soil or rhizosphere". Biostimulants include various kinds of substances, categorized in different ways over the years [21]. Du Jardin [22] classified them into seven different categories: Humic/Fulvic acids, Seaweed/Botanical extracts, Protein hydrolysates, Biopolymers, Beneficial minerals, Beneficial bacteria, and Beneficial fungi. Later on, this system was revised by Bulgari et al. [23], who added another category including extracts from industrial or food wastes and grouped nanomaterials and nanoparticles into the category of biopolymers. Recently, we focused attention on a group of pure organic products cited in the literature as having the proven ability to improve plant tolerance against abiotic stress [18], regardless of the previously established classifications of biostimulants.

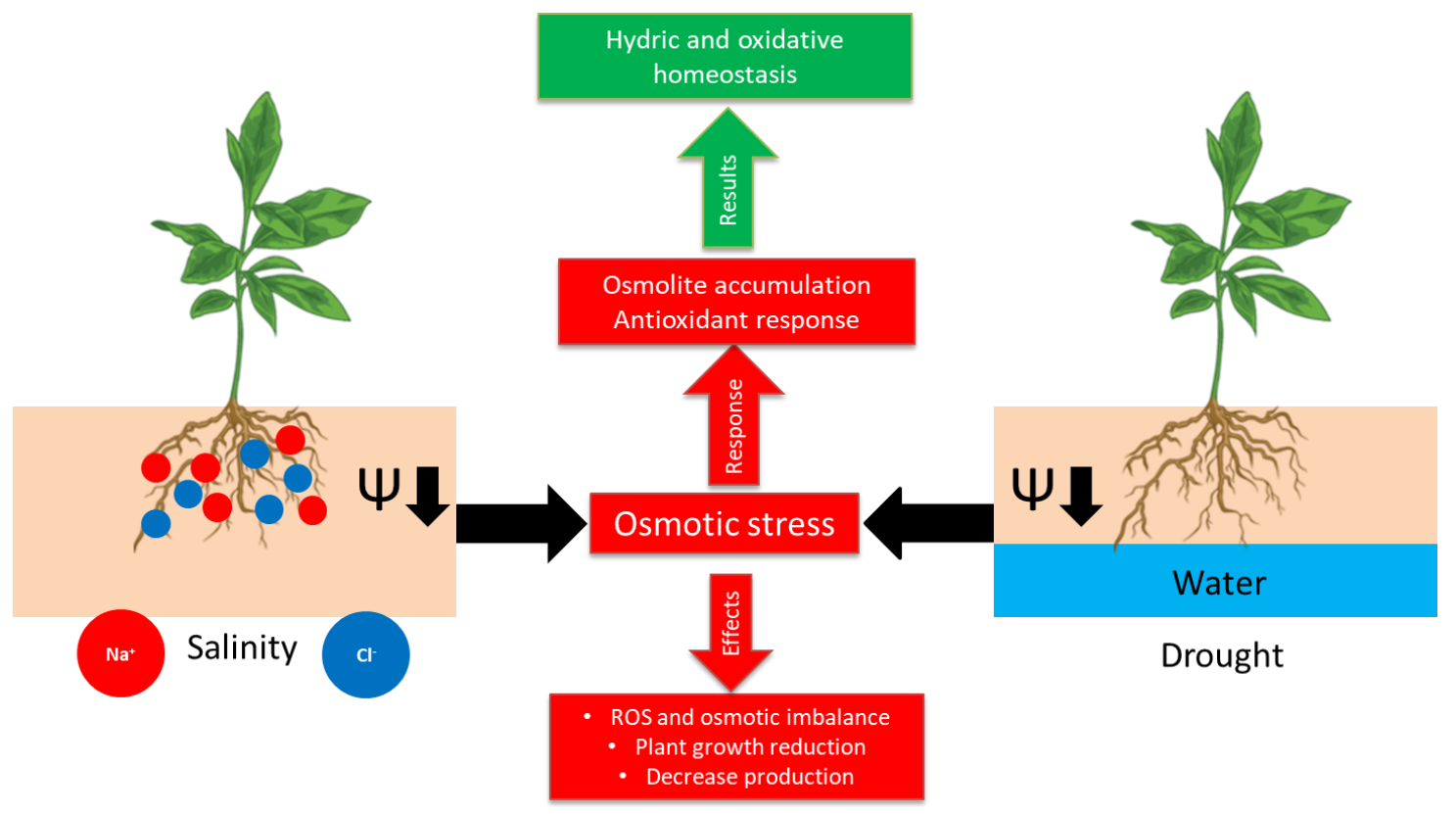

Figure 1. Schematic model of osmotic stress.

The global market in biostimulants is expected to reach $\$ 4.14$ billion by 2025 [24]. In fact, many companies have already developed formulations to improve productivity under stress. These usually consist of extracts or hydrolysates from various sources $[25,26]$, mixed with beneficial compounds acting alone as osmoprotectants [18]. This illustrates how important it is to consider the synergic effects between several molecules acting together. Indeed, it should be the best approach to combat osmotic stress, rather than the idea of finding a "magic bullet" capable of mitigating the insults alone. The aim of this review was to examine the literature and present a wide range of biostimulant sources (Figure 2) with a demonstrated capacity to increase tolerance to osmotic stress. We group them into three main categories: (1) naturally accumulated plant osmoprotectants; (2) natural 
and non-natural plant protectant compounds; and (3) hydrolysed biological extracts and microorganisms. This particular classification may help researchers that are beginning to delve into the field of biostimulants.

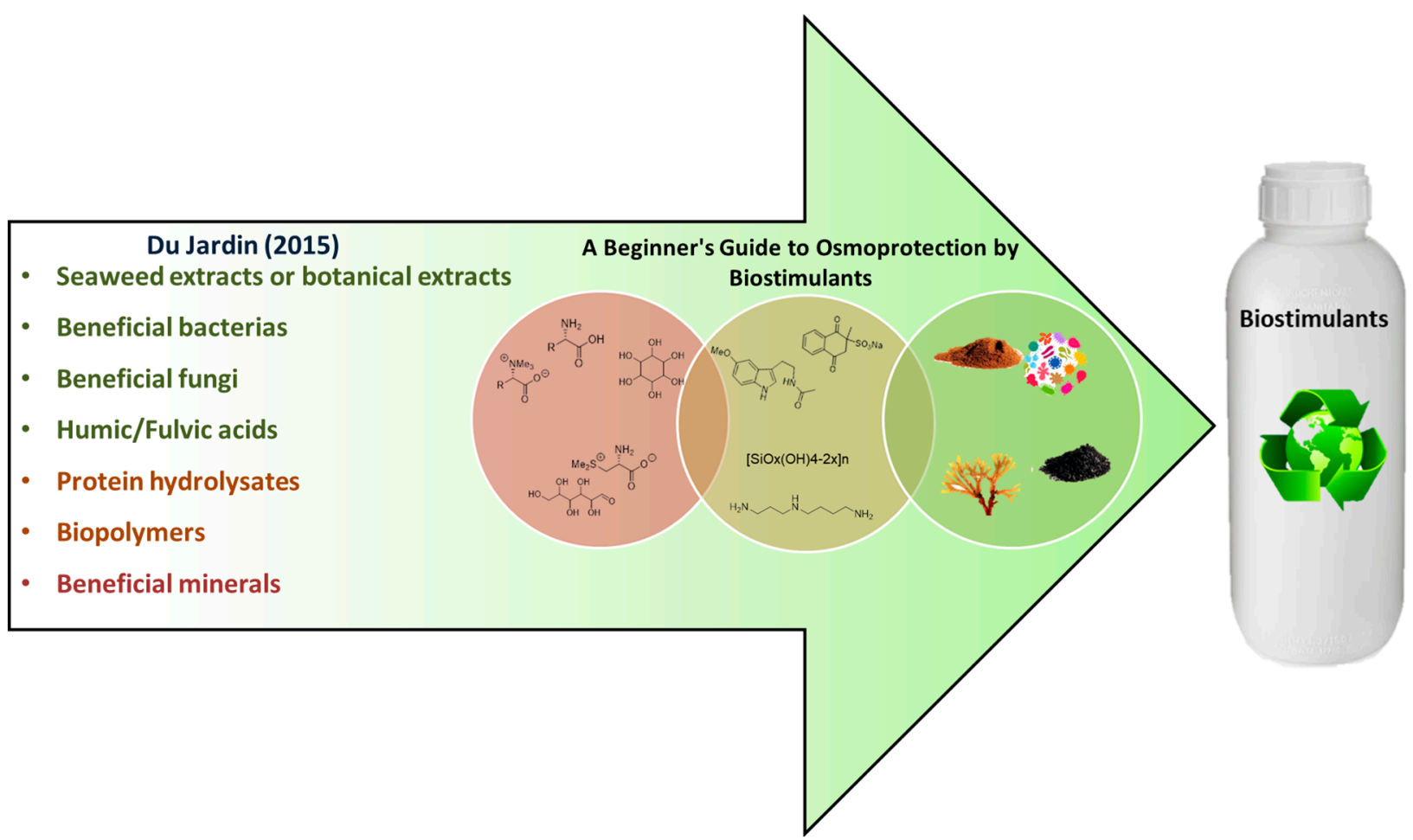

Figure 2. Graphical summary of the components listed in the review: in red, naturally accumulated plant osmoprotectants; in brown, natural and non-natural plant protectant compounds; and in green, hydrolysed biological extracts and microorganisms.

\section{Naturally Accumulated Plant Osmoprotectants}

A number of bacteria, seaweeds and plants are able to accumulate several types of compounds called compatible solutes or osmoprotectants to face osmotic stress, for instance amino acids (proline, glutamate, etc.), carbohydrates (trehalose), sugar alcohols (inositol, mannitol), quarternary ammonium compounds (glycine betaine) [27] and tertiary sulphonium compounds (e.g., dimethylsulphoniopropionate) [28].

\subsection{Amino Acids: Their Involvement in Osmotic Adjustment}

Amino acids are probably the group of compounds most used in biostimulation, offering a solid correlation with improvements in coping with osmotic stress [29,30]. Commercially, the normal way to achieve this is to use protein hydrolysates from a diverse range of sources. For an interesting review focused on commercial biostimulant formulation, see Madende and Hayes [24]. We wish to point out several amino acids that interact within osmotic adjustment in plants and can clearly induce tolerance.

Proline is probably one of the most studied amino acids acting against stress. It is accumulated in eubacteria, protozoa and plants, and is reported to aid in facing drought and salt stress by balancing the adverse osmotic potential that prevents water uptake [31]. Proline biosynthesis thus assists plants in the acclimation process. Two such pathways are described in plants: ornithine or glutamate. The glutamate pathway seems to be controlled by osmotic stress [32]. Specifically, it begins with pyrroline-5-carboxylate synthetase (P5CS) that uses ATP and NADPH to reduce initial glutamate into glutamate-semialdehyde, which converts spontaneously to pyrroline-5-carboxylate [33]. P5C is reduced to proline by the action of $\mathrm{P} 5 \mathrm{C}$ reductase (P5CR), using NADPH and $\mathrm{H}^{+}$[33]. In most plant species, P5CS is 
encoded by two genes, P5CS1 and P5CS2, while P5CR is encoded by only one [33]. Proline metabolism is particularly interesting owing to the intracellular localization of P5CS in chloroplast and cytoplasm. Proline biosynthesis requires using high amounts of NADPH and ATP. In chloroplasts, it is thought to contribute to maintaining a low NADPH:NADP ${ }^{+}$ ratio, thus sustaining electron flow in the photosynthetic chain, stabilizing redox balance, and finally reducing photoinhibition and consequent damage to the photosynthetic apparatus [34]. The osmotic stress degradation pathway is down-regulated, ensuring free proline accumulation. After stress, proline is catabolized in mitochondria, supporting oxidative respiration with energy to resume growth after stress. Indeed, complete oxidation of proline would yield 30 ATP molecules (Figure 3). Therefore, proline reserves are valuable not only in osmotic adjustment during acclimation, but also to facilitate recuperation after stress [35].

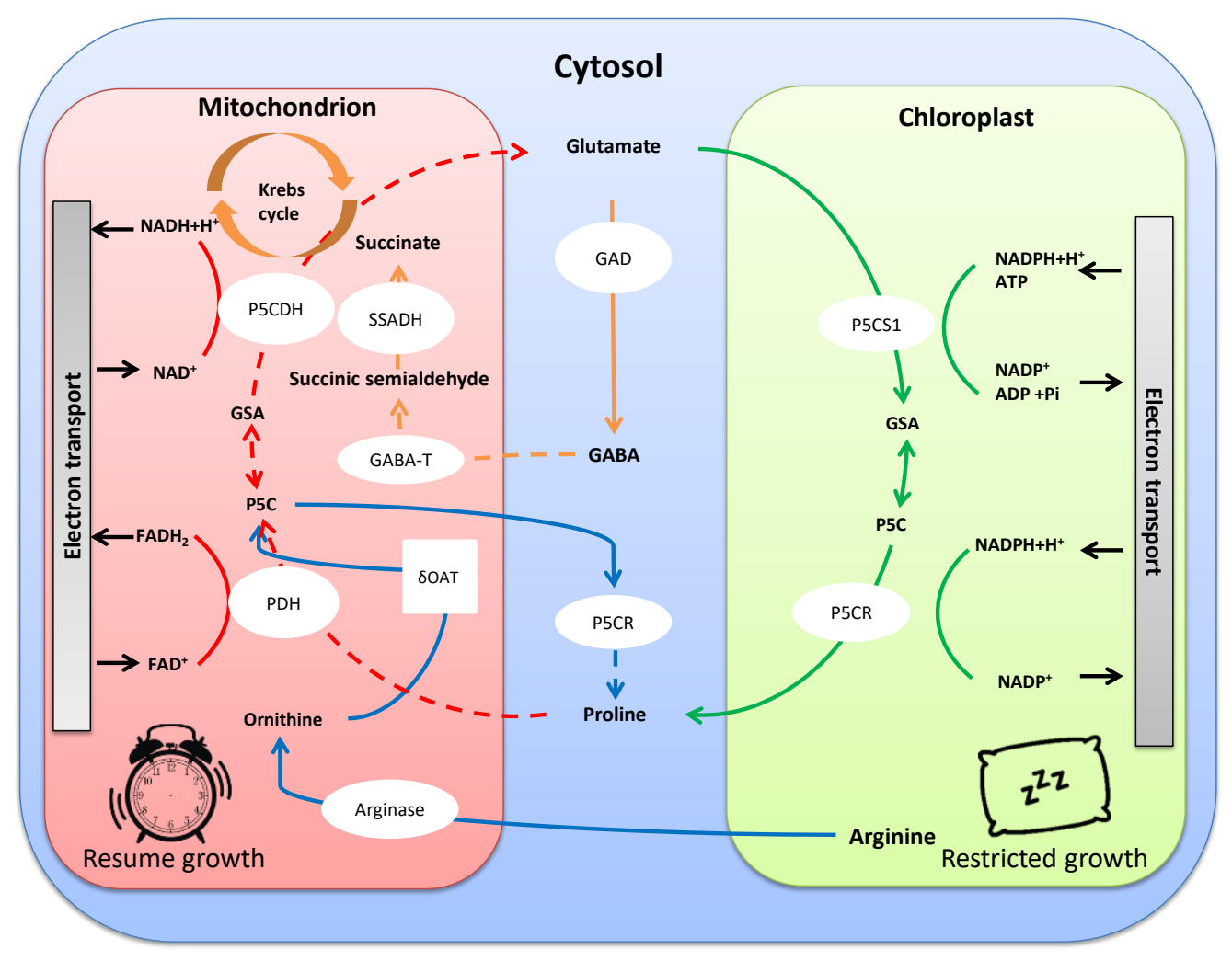

Figure 3. Importance of amino acid anabolism under stress (continuous arrows) to keep the NADPH:NADP ${ }^{+}$ratio low in the photosynthetic chain, preventing photoinhibition. Amino-acid catabolism (dashed arrows) provides energy for plant growth to resume.

Osmotic stress induces genes involved in proline biosynthesis, which leads to proline accumulation. This was demonstrated by Székely et al. [36], who knocked out p5cs1 in Arabidopsis plants to produce a salt-sensitive mutant. Exogenous application of proline can improve tolerance to salt stress through regulation of the endogenous proline metabolism. For instance, foliar application of proline to maize resulted in decreased P5CS activity and an increase in PDH under salt stress [32]. In accordance with the attributes to be expected from its metabolism, proline treatment is capable of alleviating lowered photosynthetic activity and enhancing water relations under salt stress in Olea europaea L. cv Chemlali [37]. Moreover, it can stabilize mitochondrial electron transport complex II, membranes, proteins and enzymes such as RUBISCO [38]. In Sorghum bicolor [39], it was also shown how this proline treatment increases growth under stress conditions. Finally, as a further example of ongoing research, Abdelaal et al. [40] illustrated how proline can increase production under 
salt stress. Indeed, altogether the weight of evidence demonstrates the osmoprotectant effect of exogenous proline treatment.

Glutamate is a central molecule in amino acid metabolism in higher plants. In this regard, the $\alpha$-amino group of glutamate is directly involved in assimilation and dissimilation of ammonia and is transferred to all other amino acids, since it is the precursor of $\gamma$-aminobutyric acid (GABA), arginine, and proline. It should also be noted that glutamate is the precursor for chlorophyll synthesis in the developing leaves [41]. Plants can synthesize glutamate by various pathways, principally via the glutamine synthetase/glutamine- $\alpha$-oxoglutarate transaminase cycle in the chloroplast. Otherwise in non-photosynthetic tissues, they can proceed via glutamate dehydrogenase in the mitochondria or cytoplasm. Finally, plants can also produce glutamate by the alternative pathways pro/pyrroline 5-carboxylate cycle and transamination [42]. Glutamine synthetase/glutamine- $\alpha$-oxoglutarate transaminase is the key cycle for assimilation of ammonium in plant cells. However, in tobacco plants under salt stress, its activity did not change significantly, but glutamate dehydrogenase activity increased. This is a stage in the glutamate synthesis pathway under stress, where it acts as a proline precursor [43]. These results were partially supported by Wang et al. [44]; since at low salinity the authors found that glutamine synthetase was the preferred active enzyme increasing photorespiration, while at high salt concentration it was glutamate dehydrogenase.

Glutamate treatment is rapidly converted to other amino acids, such as glutamine, GABA or proline in rice roots [45]. Under salinity stress, treatment with glutamate acts as a precursor of proline to cope with salinity stress [46]. In fact, foliar treatment of Brassica napus L. under drought stress with glutamate can increase P5CS expression [47], leading to proline accumulation and better osmotic adjustment.

$\gamma$-aminobutyric acid (GABA) is a widely distributed non-proteinogenic amino acid and a significant component of the free amino acid pool in bacteria, fungi, plants and animals. Under stress, GABA production increases, quickly reaching higher concentrations than other amino acids involved in protein synthesis [48]. Its biosynthesis begins from glutamate by action of glutamate decarboxylase, and accumulation leads to $\mathrm{H}^{+}$or $\mathrm{Ca}^{2+} /$ calmodulin, which activates the enzyme to yield GABA (Figure 3). The amino acid can be exported to the mitochondria and, after several enzymatic steps, transformed to succinate, the main energy source for the tricarboxylic acid cycle $[49,50]$. This route is known as the GABA shunt and links primary and secondary carbon and nitrogen metabolisms [42,51]. Interestingly, Shelp et al. [52] found that GABA transaminase activity (the first enzyme involved in the shunt) was inhibited under stress conditions. This suggests that GABA accumulation would be useful for the provision of anaplerotic succinate for the Krebs cycle, while awaiting the end of the stress. These data are supported by trials with GABAdeficient mutants her1 and gaba-t/pop2-1, in which no GABA-derived succinate was found in roots after salt stress ended [53,54].

The involvement of GABA in osmotic regulation was shown by using the mutant line gad1/2 in Arabidopsis. In response to water deficit, its leaves had lower relative water content (RWC), higher abaxial and adaxial stomatal conductance, and wider stomatal opening, compared to the wild type [55]. In addition, GABA treatments are able to increase tolerance of osmotic stress in rice [56], improving ionic and redox balance to reach better osmotic adjustment by accumulation of organic osmolytes such as proline, sugar and starch.

Arginine is an interesting amino acid in plant metabolism, since it has the highest nitrogen/carbon ratio of the 21 proteinogenic amino acids, and is apparently a precursor of NO and also a well-documented precursor of polyamines. Synthesis in chloroplasts via ornithine is apparently the only operational pathway to provide arginine in plants, although in fact arginine biosynthesis is poorly studied in plants [57]. One of the products of arginine hydrolysis is ornithine, by means of ornithine $\delta$-aminotransferase, which is hypothesized to play an important role in osmotic adjustment under stress. However, ornithine $\delta$-aminotransferase activity has been correlated with proline accumulation in 
salt-stressed plants [58]. Overexpression of this enzyme in rice resulted in higher proline levels and activated antioxidant defence, thus enhancing stress tolerance [59].

In particular, arginine treatment improves antioxidant defences in plants; indeed, Nasibi et al. [60] researched into a foliar application that enhanced the detoxification response, lowering $\mathrm{H}_{2} \mathrm{O}_{2}$ content under water stress. External treatment can also increase proline accumulation in mung bean under salinity stress, protecting its growth [61].

\subsection{Carbohydrate Sugars}

Carbohydrates are crucial molecules for living organisms. Chemically they are aldehydes and ketones with several hydroxyl groups and varying degrees of polymerization (monosaccharides, disaccharides, oligosaccharides and polysaccharides), containing atoms of carbon, hydrogen, and oxygen [62]. They exert structural, signalling, carrying and storage functions. The part they play in the plant's response to stress has been associated with their high potential for polymerization. Due to their solubility, some of them: sugars such as hexose and fructans (and also sugar-alcohols like mannitol and sorbitol—see below) can act as compatible solutes, contributing to osmotic balance and membrane and protein stabilization under osmotic stress conditions [62,63]. These substances clearly act as osmoprotectants [64], since a number of studies have demonstrated that accumulation of reduced forms of sugars has an osmoprotective function against drought and salt stress [65].

Starches are also emerging as key substances in mediating plant responses to abiotic stresses, such as water deficit and high salinity. They consist of two types of molecules: linear and helical amylose and the branched amylopectin. Depending on the plant, starch generally contains 20 to $25 \%$ amylose and 75 to $80 \%$ amylopectin by weight. Under challenging environmental conditions, plants generally remobilize starch to provide energy and carbon at times when photosynthesis becomes limited. It is therefore used for many plant species as an acclimation strategy in harsh environments [66]. Fructans are considered short-term storage carbohydrates and have been associated with stress tolerance mechanisms for many years [67]. This is especially the case with freezing tolerance, since desiccation is a key component in some research focused on studying the possibility to alleviate drought stress using fructans. On this topic, Su et al. [68] showed how the 1fructosyl-transferase gene from a fructan-accumulating plant increases tolerance against osmotic stress induced by PEG in tobacco plants. These fructans may indirectly contribute to osmotic adjustment by releasing hexose sugars [67]. Raffinose family oligosaccharides are characterized as compatible solutes involved in stress tolerance, and are accumulated under drought stress [69]. However, despite their osmoprotective action, we have not found reports of these compounds used as biostimulants.

Soluble sugars such as sucrose, glucose and fructose are important not only as nutrients but play other roles in metabolism, growth and stress responses [70]. Their accumulation as osmolytes serves to help plants face the negative effects of osmotic stress [71]. As an example, treatment with glucose enhances salinity tolerance in wheat seedlings by preventing water loss through proline accumulation and maintaining ionic balance [72]. It was earlier shown that soluble sugar accumulation enhances proline content and thus helps the plant to counteract the osmotic insult of salt stress [73].

Trehalose is a promising carbohydrate for use as a biostimulant. It is a non-reducing disaccharide consisting of two glucose units ( $\alpha$-D-glucopyranosyl-1,1- $\alpha$-D-glucopyranoside) and is widely spread in a variety of organisms: bacteria, yeast, fungi, lower and higher plants, as well as insects and other invertebrates [74]. Its biosynthesis in plants occurs in two steps: trehalose-6-phosphate synthase generates trehalose-6-phosphate from uridine diphosphate UDP-glucose and glucose-6-phosphate, followed by dephosphorylation to trehalose by trehalose-6-phosphate phosphatase [75]. Some work using genetic engineering provides evidence that an enhanced metabolism can positively regulate osmotic stress tolerance. As an example, Ge et al. [76] showed how over-expression of OsTPP1 caused higher tolerance to salt stress in rice. See Fernandez et al. [77] for an extensive review of the action of trehalose in stressed plants. Trehalose can be used as a treatment to enhance 
tolerance against salt stress in strawberry [78], protecting plants from oxidative damage caused by salt and conserving the photochemical function. Moreover, trehalose treatment is capable of enhancing osmoregulation in wheat.

\subsection{Sugar Alcohols}

Also known as polyols, sugar alcohols can be structurally cyclic like myo-inositol or have a linear structure such as mannitol or sorbitol [79]. Usually water soluble, polyols are derived from the reduction of aldoses or their phosphate esters [65]. In particular, sorbitol, a sugar alcohol with six carbons, is widely distributed in plants. It is a major photosynthetic product in apple trees, where foliar treatments suppress its synthesis and alter the stress expression profile. This suggests that sorbitol therefore plays an important part in responses to abiotic and biotic stresses in apple trees [80]. Other sorbitol treatments to elicit stress reactions remain out of the scope of this review.

Inositols are synthesized from D-glucose, involving three enzymatic steps. Hexokinase converts glucose into glucose-6P and then Ins(3)P1 synthase produces Ins(3)P1, which is the first step in myo-inositol (MI) biosynthesis. Finally, phosphate loss due the action of MI monophosphates releases free MI. This constitutes the pathway for MI biosynthesis in cyanobacteria, algae, fungi, plants, and animals and is central to their cellular metabolism [81]. Plants accumulate many kinds of inositol during abiotic stress periods caused by drought and high salinity stresses [82]. In this context, manipulation of inositol metabolic pathways can increase salt tolerance in rice [83]. Myo-inositol treatment helps to maintain cell turgor, enhancing water status in Capsicum anuum [84].

Mannitol has a wide presence in plants and fungi, with importance in the tolerance response against osmotic stress [85]. It is biosynthesized in the plant cell cytoplasm from fructose-6P, which is transformed by phosphomannose isomerase into mannose 6phosphate, then mannose-6-phosphate reductase transforms it into mannitol 1-phosphate. Finally, mannitol-1-phosphate phosphatase removes the phosphate to yield mannitol [85]. Abebe et al. [86] introduced the ectopimannitol-1-phosphate dehydrogenase from Escherichia coli, which enabled mannitol accumulation in wheat calluses (a plant that does not accumulate mannitol). It increased tolerance to osmotic stress and oxidative impacts by preventing water loss. This effect can be elicited using an external treatment of mannitol in wheat [87], and in maize where it can enhance proline metabolism under drought stress, improving water relations [88].

\subsection{Quaternary Ammonium Compounds}

Quaternary ammonium compounds accumulated in plants are glycine betaine, $\beta$ alanine betaine, proline betaine, choline-O-sulphate, hydroxyproline betaine and pipecolate betaine [28]. These organic compounds are known to also have osmoprotective effects in plant cells [89]; they are thus an interesting family to consider for biostimulant formulations.

Glycine betaine is accumulated by numerous organisms, such as bacteria, cyanobacteria, algae, fungi and animals. It is probably the most common quaternary product that plants accumulate to cope with osmotic stress [28]. Glycine betaine is synthesized preferentially from choline, which is converted to betaine aldehyde by choline monooxygenase. Then, it is converted by the action of betaine aldehyde dehydrogenase into glycine in all glycine betaine-accumulating plant species [28]. Some plants, such as aubergine/eggplant, potato, Arabidopsis, tomato and many rice cultivars, cannot accumulate detectable amounts of glycine betaine [90]. Therefore, genes associated with its biosynthesis have been introduced/overexpressed in these non-accumulating plants, e.g., in tomato [91] or potato [92], demonstrating the fundamental role of glycine betaine in osmoprotection against stress. Overaccumulation of this osmolyte provides tolerance in wheat against drought, due to upregulation of the betaine aldehyde dehydrogenase gene [93]. Glycine betaine is able to induce tolerance to abiotic stress after treatment, for example, in maize, modulating the ABA response against drought and salt, and preserving yield [94]. A wide number of species show better performance against drought and salt stress after treatment [16]. 
L-proline-betaine (also called stachydrine) is accumulated in non-halophytic Medicago species [95], although it is less frequently present in halophytes than glycine betaine. Interestingly, some researchers point out that proline betaine accumulation is an evolutionary response to salinization, deriving from several proline methylation steps [95]. Treatments applied in Bacillus subtilis cultures increase tolerance against osmotic stress [96] and have more effective osmoprotectant effects than proline [97]. However, as far as we know, proline-betaine has not been assayed as a plant treatment to alleviate stress, despite being a promising compound for study as a biostimulant. Finally, we must highlight that alanine-betaine acts as a compatible osmolyte in halophytic Plumbaginaceae species; this constitutes another interesting evolutionary adaptation against combined osmotic and sulphate stresses, for example. Its biosynthesis does not require oxygen (in contrast to glycine betaine), and its use may be advantageous in sulphate-rich salt marsh environments [98].

\subsection{Tertiary Sulphonium Compounds}

These substances are an interesting family of compatible osmolytes, scarcely studied in comparison to other groups and of course even less as biostimulants. For instance, the known anti-stress compound dimethylsulphoniopropionate (DMSP) is synthesized in many algae but only a few plants, notably genus Spartina and in sugarcane [99]. It is also accumulated in some cyanobacteria and bacteria [100]. The precursor of DMSP is methionine and its involvement in osmoregulation is based on structural similarity with quaternary ammonium compounds. There are some studies on the osmoregulatory function of DMSP in algae, and the data presented in Spartina species provide evidence to consider it an osmoprotectant [99]. Another compound from this family is S-methylmethionine (vitamin $\mathrm{U})$, produced by all angiosperms. Treating plants with it to enhance cold tolerance has been studied [101,102], but to date its application against salt or drought stress has not been.

\section{Natural and Non-Natural Plant Protectant Compounds}

Several treatments are capable of increasing plant tolerance to such stresses, such as those with polyamines [103], silicon [10], menadione sodium bisulphite [104], and melatonin $[105,106]$. These compounds are promising options to aid in further understanding the response mechanism under osmotic stress or also biostimulation processes.

\subsection{Polyamines}

These are nitrogen-containing aliphatic compounds with low molecular weights. At the physiological level they are positively charged, regulating $\mathrm{pH}$ among cellular components [107]. These compounds bind electrostatically with great affinity to macromolecules, such as proteins, DNA, and RNA [108]. As important examples, putrescine, spermine, spermidine, and other phytohormones that contain aliphatic amines are found in bacteria and animals, besides plants [109]. Polyamines (PAs) play a key part in essential biochemical/physiological processes: development, cell proliferation, signal transduction and senescence. They are important in gene expression, and respond to stresses in eukaryotic and prokaryotic cells. Several papers confirm that plants accumulate an enormous quantity of PAs to face a range of both abiotic and biotic stresses [109,110].

Polyamine syntheses begin with the formation of putrescine, for instance, by direct decarboxylation of ornithine through the activity of ornithine descarboxylase. However, putrescine can also be synthesized from arginine by decarboxylation into agmatine by action of arginine decarboxylase, followed by agmatine iminohydrolase and N-carbamoyl putrescine aminohydroxylase to produce putrescine [111]. Spermidine is formed from putrescine by the action of the spermidine synthase, and finally spermine is catalysed through the intervention of spermine synthase [111].

External polyamine treatments can increase tolerance against osmotic stress:

1. Putrescine is capable of protecting photosynthetic machinery in cucumber under salt stress [112]. It can also improve gas exchange parameters [113]. 
2. Spermidine improves drought tolerance in maize [114] by strengthening antioxidant defences. Under salt stress it enhances reactive oxygen species (ROS) scavenging to promote tolerance [115].

3. Spermine increases tolerance to salt stress in tomato by enhancing the chloroplast antioxidant system [116]. Drought effects can be mitigated by spermine treatment in maize [117], alleviating photosynthesis inhibition.

4. Farooq et al. [118] researched into treatments applying the three polyamines to rice, to ameliorate drought stress. Their study showed how the best results in controlling water loss were obtained by foliar application of spermine. Nevertheless, putrescine and spermidine had superior results in scavenging ROS radical, with a better enzymatic response.

5. Thermospermine is synthesized by thermo-spermine synthase and is less well known than the other three polyamines. It has not been used as a treatment against stress, but its potential is worthy of mention because a thermospermine-deficient mutant is hypersensitive to salt in Arabidopsis thaliana [119].

\subsection{Silicon}

The physiological roles of silicon in animals have been known for more than a century. Nevertheless, its specific benefits to plants, particularly under stress, have only recently been under intensive study. This is mainly due to it being labelled a "non-essential" element by plant nutritionists [120]. Certainly, Si is not deemed "essential" to vascular plants, since they can carry on their life cycles in its absence. Some plants are silicon accumulators, such as rice and sugarcane [121]. Interestingly, other plants defined as non-accumulators have beneficial effects after silicon treatment. As an example, tomato is not a silicon accumulator; moreover, it is considered an excluder, but it is clearly established that this metalloid can increase tolerance against salt stress [122].

Silicon can be applied in several forms:

1. $\mathrm{K}_{2} \mathrm{SiO}_{3}$ has been applied in wheat to alleviate drought stress [123], in common bean to enhance salt stress tolerance [124], and can increase yield under drought stress [125].

2. $\mathrm{Na}_{2} \mathrm{SiO}_{3}$ is able to improve salt stress tolerance in barley [126] and in maize growing under drought stress [127]. However, as far as we know, increased production under stress was not reported using this silicon compound.

3. $\mathrm{SiO}_{2}$ is applied using micro- or nanoparticles to alleviate the deleterious effects of drought in rice [128] and salinity in potato. Indeed, it is possible to increase yield under drought stress using these nanoparticles [129].

4. $\mathrm{H}_{4} \mathrm{SiO}_{4}$ can induce drought tolerance, increasing yield and enhancing fruit quality in watermelon [130].

Silicon aids the plant to cope with osmotic stress in various ways. Two processes contribute to stress tolerance: (i) mechanical and physical protection due to $\mathrm{SiO}_{2}$ deposits known as phytoliths; (ii) biochemical responses that trigger metabolic changes [131]. Silicon can influence water relations in plants submitted to drought, reducing water lost through cuticular transpiration and stomatal conductance [132]. Interestingly, transpiration rates decrease with increasing Si content in shoots [133]. Directly counteracting salinity stress, it can raise $\mathrm{Na}$ and $\mathrm{Cl}$ uptake $[132,134]$.

\subsection{Vitamin $K_{3}$ (Menadione Sodium Bisulphite)}

This vitamin is erroneously thought to have only a synthetic origin, whereas it can be isolated from fungi, cryptogams and phanerogams, although its functions are still unclear [135]. Our research group has studied in depth the anti-stress properties of a water-soluble derivative called menadione sodium bisulphite (MSB). Besides its capacity to induce resistance against many plant pathogens and pests [136,137], this molecule increases tolerance to seed treatment against salt stress in Arabidopsis [138], by root treatment [139], or foliar application [140]. Treatment under salt stress triggers a slight oxidative burst that elicits plant defences that lead to a faster relative growth rate, with enhanced water status 
and gas exchange parameters [139]. Interestingly, treatment demethylated the promotor of the P5CS gene in Arabidopsis, causing an earlier response in proline metabolism and better osmotic adjustment [141]. Furthermore, MSB also enhanced scavenger responses and prevented toxic $\mathrm{Na}^{+}$levels by the expression of regulating proteins, thus improving ionic homeostasis under salt stress [139]. Beyond the clearly demonstrated greater tolerance to salt stress, foliar treatment with MSB also slightly improved drought stress response during the first steps of stress exposure in broccoli [142]. Additionally, MSB has been shown to induce tolerance against heavy metals such as cadmium [143] and chromium [144].

\subsection{Melatonin}

A compound almost universally present in animals, melatonin is also in plants, where it is distributed in various organs, such as leaves, stems, roots, fruits and seeds [145]. In a wide range of plant species, melatonin biosynthesis begins with tryptophan being transformed to tryptamine by tryptophan decarboxylase, then tryptamine 5-hydroxylase catalyses the conversion of tryptamine to serotonin. Serotonin is converted to N-acetylserotonin by serotonin/arylalkylamine $\mathrm{N}$-acetyltransferase, and finally into melatonin by N-acetyl-serotonin /hydroxyindole O-methyltransferase [146]. Melatonin is involved in numerous plant metabolic processes (for an extensive review, see Back [147]) and has a prolific bibliography, particularly due its involvement in enhanced plant tolerance to abiotic stress.

Under unfavourable environmental conditions, plants accumulate melatonin [148]. In this regard, overexpression of the genes involved in melatonin biosynthesis enhances drought tolerance [149], confirming its implication in plant defences against osmotic stress. Exogenous treatment with melatonin also induces resistance against salt stress in maize, ameliorating oxidative stress and adjusting ion balance [150]. Similarly, the effect of exogenous melatonin on the antioxidant system can increase drought tolerance in kiwi-fruit seedlings [151]. In addition, the treatment impedes water loss in stressed plants. Interestingly, 2-hydroxymelatonin is more common in plants, the average ratio being approximately $368: 1$, but the compound predominantly used as a biostimulant is melatonin. Despite this, some authors have demonstrated the former's less studied capacity to induce tolerance to drought stress [152].

\section{Extracts from Natural Sources and Microorganisms}

In biostimulant formulation, manufacturers normally use complex mixtures from a range of sources. In addition to the compounds described above, in this review, we must include seaweed extracts, microorganism-based biostimulants and humic and fulvic substances.

\subsection{Seaweed Extracts}

In recent decades, after a notable boom in 1947 in the United Kingdom [153], the use of macroalgal extracts as a source of biostimulants for agriculture has again been on the rise commercially, in the form of plant-growth-promoting factors to enhance salinity, drought and heat tolerance. These preparations act on several biochemical pathways to improve stress resistance. Among these, they induce ROS-scavenging enzymes, membrane stability and an increase in osmoprotectant compounds such as Pro and glycine-betaine [153].

Red, green, and brown seaweeds amount to $10 \%$ of the sea's biomass productivity. Currently, a wide number of companies process and market their extracts for agriculture as biostimulants, which leads to reduced consumption of mineral amendments with their heavy carbon footprint [154]. The most commonly used extraction methods are mechanical disruption, alkalis or acids, and pulverization [153], but other novel techniques could lead to further final biostimulants. It is therefore necessary to evaluate not only the source but also the methodology, to provide a consistent biostimulant effect on crops [155]. Even though the growth-promoting effects of such extracts are reported for a range of crops, the mechanisms underpinning their influence are still not known. The complex chemistry of macroalgae makes it hard to establish exactly which are the active components [156]. In 
fact, algae have a plethora of osmoprotectant compounds that are able to increase tolerance against stress, such as: ions like $\mathrm{Ca}^{2+}$, amino acids, betaines, carbohydrates, flavonoids, phenolic acids, phytohormones, polyols, and tertiary sulphonium [157]. We need to point out that seaweed extracts are an excellent source of phytohormones [158] and that water stress reduces cytokine levels and increases ABA biosynthesis in plant tissues. Cytokinins are in fact key phytohormones that not only regulate plant growth and development but also mediate plant tolerance to drought stress [159]. Seaweed extracts thus act positively on chlorophyll synthesis, keeping cytokinin concentrations high and hindering ABA synthesis. The algal extracts most used as biostimulants are the following:

1. Ascophyllum nodosum has a demonstrated effect as biostimulant (see Shukla et al. [160], for a complete review), being able to enhance tolerance against drought stress, for example, in tomato [161] and avocado plants exposed to salt stress [162]. Under salinity, extracts containing this seaweed can improve water relations to cause better growth and fruit quality in tomato; although yield improvements are not yet reported [163]. Treatments with $A$. nodosum extracts provide drought stress tolerance to treated plants by reducing stomatal conductance and cellular electrolyte leakage in water-stressed plants over time, and maintaining a high leaf turgor and stem angle [164].

2. Ecklonia maxima is another macroalga used in biostimulant formulation; research was largely focused on phytohormone-like activities [165], but its effects on stress are less studied. In the literature, however, formulates based on this source are capable of inducing salt tolerance, enhancing gas-exchange parameters and increasing yield in zucchini squash (courgette) [166].

Other species are claimed by Sharma et al. [154], as source biostimulants. Mattner et al. [167] demonstrated how the use of a mixture with Durviella and A. nodosum can increase yield in strawberry without imposed stress. An extract from Macrocystis pyrifera enhanced growth in Lactuca sativa seedlings [168] and other interesting species without specific biostimulant uses reported in the literature which include: Durvillea antarctica, Fucus serratus, Himanthalia elongata, Laminaria digitata, Laminaria hyperborea, and Sargassum spp.

In recent years, biostimulants based on microscopic algae have taken on special importance, with many species acting as biostimulants: Chlorella vulgaris, Chlorella ellipsoida, Chlorella infusionum, Acutodesmus dimorphus, Scenedesmus platensis, Scenedesmus quadricauda, Dunaliella salina, Spirulina maxima and Calothrix elenkinii (see Ronga et al. [169] for an extensive review). Biostimulants using microalgae present several challenges to solve, due precisely to their novelty. Clearly, the great variability of microalgal strains yet unexploited by the biostimulant industry, and lack of knowledge regarding their biomolecular mechanisms, may still cause rejection by professionals and hamper their regular utilization in agricultural practices [170].

\subsection{Microorganisms}

It is widely accepted that plants can maintain stabilizing relationships with bacteria that help them survive numerous stressful conditions [171]. In this context, numerous researchers have attempted to isolate microorganisms from varied ecosystems with environmental constraints, such as saline, alkaline, acidic, and arid soils [172]. Microorganisms that grow in adverse environments have had to develop numerous strategies to survive, for example, changes in cell wall composition and high concentrations of soluble solutes. Consequently, these microorganisms are excellent sources of biostimulants [172] and such microbe-induced tolerance is being used against biotic and abiotic stress and enhanced soil fertility [173]. Some genera used as biostimulants are as follows:

1. Rhizobium has been described as helping plants to acclimate to abiotic stress [174]. Symbiosis with Rhizobium is reported to influence salt and drought responses in Medicago trunculata [175].

2. Trichoderma is described by Zaidi et al. [176] as a potential source for abiotic stress biocontrol; indeed, exogenous treatment can induce tolerance against salt in wheat [177] 
and cucumber [178]. It has a capacity to induce tolerance against drought in maize [179] and rice [180].

3. Bradyrhizobium can alleviate salt stress, promoting symbiosis in soybean [181]. In peanut, it helps to alleviate the negative effects of water restriction [182].

4. Azotobacter isolated from semi-arid regions is capable of alleviating drought stress after inoculation in maize [183]. It is described by Viscardi et al. [184] as a possible way to increase tolerance against abiotic stress.

5. Azospirillum can improve salt tolerance in chickpea, increasing the biosynthesis of compatible osmolytes and enhancing the antioxidant machinery [185]. Utilization of this genus was reviewed by Vacheron et al. [186].

6. Pseudomonas induces drought tolerance in mung bean [187] and salt tolerance in cotton plants [188].

7. Bacillus improves drought stress tolerance in maize, promoting better oxidative and water balance [189]. It is noteworthy that $\mathrm{Li}$ et al. [190] studied the transcriptome profile of salt tolerance conferred by a Bacillus microorganism.

Treatment with microorganisms may be a useful way to cope with new upcoming situations imposed by climate change [191].

\subsection{Humic and Fulvic Acid Extracts}

These make up more than $60 \%$ of soil organic matter and are the major component of organic fertilizers, produced by the biodegradation of organic matter, resulting in a mixture of acids containing phenolate and carboxyl groups. Fulvic acids are humic acids with a higher oxygen content and lower molecular weight [172]. One hypothesis about the mechanism of action of supplementation with these biostimulants in soils with poor organic carbon is that it helps improve microorganism stabilization and chemical characterization of the soil [192]. These authors also found that it is not economically feasible to apply them to arid soils. In addition, published data show that humic and fulvic treatments can modify the plants' primary and secondary metabolism against abiotic stress, enhancing water uptake and antioxidant behaviour under stress [193]. The application of both types of acids is widely reported in the literature as an external treatment to increase tolerance against osmotic stress (see Ali et al. $[128,194]$ for an extensive review):

1. Humic acids are able to enhance maize plants' salt response [195], increasing proline accumulation and strengthening the enzymatic antioxidant system. In Lima bean [196] it can ameliorate negative effects exerted by drought, by increasing photosynthetic activity and accumulating sugars and proline in leaves and thus a higher relative water content in these organs.

2. Fulvic acid treatment enhances water relations in citrus through higher proline accumulation in leaves and protection from chlorophyll degradation by salt stress [197] In rapeseed it can protect the photosynthetic machinery and aid the membrane to resist peroxidation [198].

Use of humic substances as a biostimulant for plant growth is a promising eco-friendly approach, in accordance with the concept of circular economy. It focuses on a progressive conversion to resources whose consumption can itself alleviate anthropic impacts and pressure, and the impending consequences of climate change [194]. Finally, there is interesting research where the authors try to isolate humic substance structures and associate them with their activity in plants $[199,200]$, laying the basis for a better understanding of this structurally complex type of biostimulants.

\section{Biostimulants' Field Applications}

The European Biostimulant Industry Council also reported that more than 6.2 million hectares in the EU have already been treated with biostimulants. Developments in this field are definitely focused on looking for new compounds or mixes that can be applied to increase and economize crop production by reducing costs. Yakhin et al. [21] provide interesting information about one of the most famous biostimulants on the market. 
Biostimulants can be administered in the field by foliar or fert-irrigation, for example, amino acids are normally applied as protein hydrolysates. This kind of product may proceed from animal or plant sources. They are quickly gaining popularity in the industry and with farmers, because they contain a large number and quantity of bioactive compounds and have proven efficacy in enhancing crop performance, even under stress conditions [26]. Biostimulants based on amino acids are suitable for foliar application, increasing yield and grain quality after two treatments with these commercial formulations [201]. Foliar treatments are also able to increase yield under saline growth conditions [202] or growth under water deficit conditions $[203,204]$. Amino acid formulations can also be applied by fertirrigation to enhance fruit quality [205], improving yield under water restriction [206]. In an interesting review, Moreno-Hernandez et al. [207] summarize commercial biostimulants prepared from protein hydrolysates in a table showing their application method and crop responses. Basie et al. [208] review how biostimulants from different sources have been applied to fruit trees, grapevines and berry crops against abiotic stress, including drought and salinity. In an interesting field experiment, Kocira et al. [209] used foliar treatments of seaweed- or amino-acid-based biostimulants. Both increased yield, but the profits using seaweed extracts are higher in comparison to amino acids: EUR 752.57. $\mathrm{ha}^{-1}$ to EUR 119.67· ha $^{-1}$, respectively (Figure 4 ).

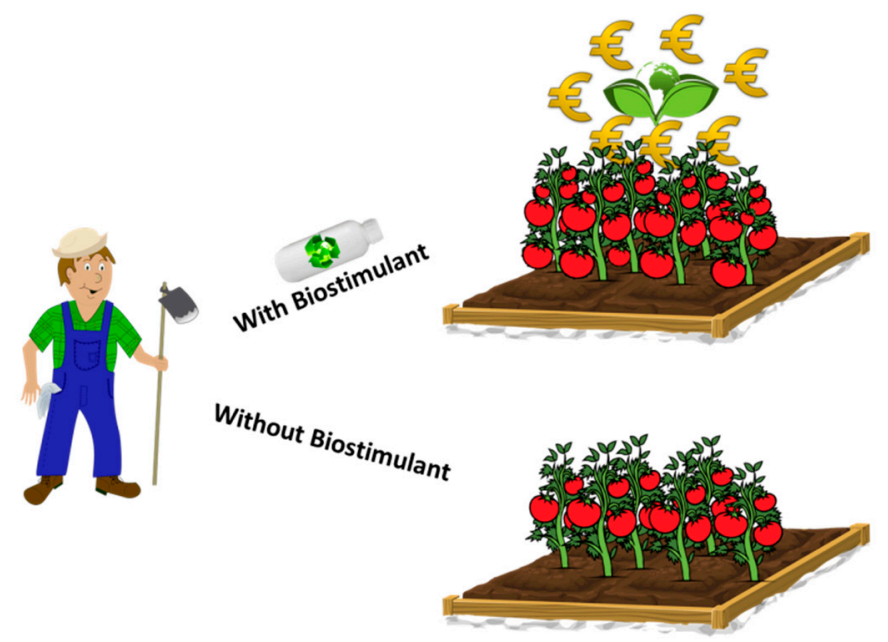

Figure 4. Biostimulants have the potential to increase crop productivity in a sustainable way.

\section{The Future of Osmoprotection}

\subsection{What Chemical Modifications Can Be Learned from Nature and Applied to Single Molecules?}

Plants are incredibly resilient organisms that have to live their whole life cycle in the place that a seed or other propagule was deposited. Due to their sessile nature in the environment, we provide a few examples that demonstrate which plants have similar strategies but with different final results. One group of compounds that probably best represents this concept are the non-proteinogenic amino acids, used by plants as a response to different kinds of stress [210]. Beyond GABA accumulation under osmotic stress (see above), a plethora of non-proteinogenic amino acids are synthesized by plants. As an example of this, after studying the metabolic response against osmotic stress in tolerant and sensitive varieties, one of the most abundant compounds in roots of the tolerant variety was found to be $\beta$-alanine [211]. It acts as a precursor of $\beta$-alanine betaine, which acts as osmoprotectant in some halophytic plants [212].

Another interesting response is osmoprotection in watermelon; besides the usual accumulation under stress of proline, watermelon complements this by accumulating citrulline. Under stress, the latter represents $21-25 \%$ of the total amino-acids in watermelon stem and leaves [213]. These particular responses offer opportunities to use modern omic technologies. Stress-tolerant or sensitive varieties can be compared using metabolomic 
tools to detect and evaluate the differences arising from the interactive coevolution of plants with their environments [214]. In this way, the search continues for new compounds to further the advance into various fields of biostimulation [215].

\subsection{New Strategies to Find New Active Biostimulants}

In the literature, there are already plenty of approaches to studying differences in tolerance of different crop cultivars, but surprisingly we have not found examples of their use with biostimulants. Here, we discuss some strategies that in our opinion have great screening potential.

Infra-Red thermography is able to detect excess heat emitted from stressed plants [216]. Applying this, Siddiqui et al. [217] demonstrated how the leaf temperature of plants submitted to drought stress increases in a high correlation with relative water content and osmotic potential, and a good correlation with stomatal conductance. Others have used drought-tolerant maize genotypes or salt-tolerant cereals $[214,218]$. One of the drawbacks of this approach has been the need to use a thermal camera, but recently some papers show how a cheap camera coupled to a smartphone is adequate for infra-red thermography studies [219].

The infrared approach can be used within a high-throughput phenotyping platform, such as that described by Kim et al., [218]. This is able to measure plant area, colour, compactness, seed/cereal water content, and photosynthetic efficiency in real time, using image technology and DroughtSpotter. The latter is a lysimeter that assesses water use and transpiration rates based on weight measurements, Phenospex@. Another interesting phenotyping platform measures root and shoot growth ratio in real time [220], which is very useful to take into account in plant breeding against osmotic stress because it normally increases in response to drought [221]. This type of expensive equipment would seem utopic for the majority of researchers but the European Council offers opportunities to use such platforms within the European Plant Phenotyping Network. This leads in interesting directions for new biostimulant development. Rouphael et al. [222] review High-Throughput Plant Phenotyping systems for developing new biostimulants, providing interesting alternatives to perform experiments with transfer from laboratory to field.

\section{Future Remarks}

Plans such as the 'new green deal' include a search for field treatments that protect crops without environmental cost. In fact, biostimulants are a promising bet for inclusion in the forthcoming new deal. This has to be faced in a multidisciplinary way, because understanding metabolism under both stress and its alleviation is the key to increased production. In our opinion, this area needs deeper study focused on production and agronomy. In Garcia-Garcia et al. [18], we presented a more detailed review focused on production. After an exhaustive bibliographical search, only 6\% of more than 182 papers about biostimulants take into consideration final yield, which is in the end the main purpose of biostimulant utilization. Another important problem with biostimulant research is the exposure to extremely strong stresses, feasible in the laboratory but practically impossible to find in a commercial plantation. A closer model to agricultural reality was our field trial using lettuce as a crop; plants were submitted to stress levels that ensured production but with a considerable impact on it [206]. Although lettuce is a good option for first trials with a biostimulant, it only permits stress protection to be evaluated in terms of vegetative growth. Fruit production is more important in commercial crops, so more research in this latter line is necessary.

Author Contributions: Conceptualization, A.A.B. and D.J.-A.; writing-original draft, A.A.B. and D.J.-A.; review and editing, J.C.L., A.J.H., D.J.-A., F.J.G.-M., A.L.G.-G., F.V., S.M.-S.; figures and table editing: A.J.H., D.J.-A. and A.A.B. All authors have read and agreed to the published version of the manuscript. 
Funding: This review was partly financed by the project AHIDAGRO (MAC2/1.1b/279), Cooperation Programme INTERREG-MAC 2014-2020, with European Funds for Regional DevelopmentFEDER. A.L.G.G. and F.J.G.M. held predoctoral contracts from the Agencia Canaria de Investigación, Innovación y Sociedad de la Información (ACIISI) and European Social Found (ESF).

Acknowledgments: The manuscript was revised by G. Jones, funded by Cabildo de Tenerife under the TFinnova Programme, supported by MEDI and FDCAN.

Conflicts of Interest: The authors have no conflict of interest.

\section{References}

1. United Nations, Department of Economic and Social Affairs, Population Division. World Population Prospects 2019: Highlights (ST/ESA/SER.A/423); United Nations: New York, NY, USA, 2019.

2. Hunter, M.C.; Smith, R.G.; Schipanski, M.E.; Atwood, L.W.; Mortensen, D.A. Agriculture in 2050: Recalibrating Targets for Sustainable Intensification. BioScience 2017, 67, 386-391. [CrossRef]

3. Hameed, M.; Ahmadalipour, A.; Moradkhani, H. Drought and food security in the middle east: An analytical framework. Agric. For. Meteorol. 2020, 281, 107816. [CrossRef]

4. Cotterman, K.A.; Petri, A.C.; Westervelt, J.D.; Rhodes, A.M. Projecting Changes in Food Security throughout Central America; Engineer Research and Development Center United States: Vicksburg, MS, USA, 2020.

5. Mahlknecht, J.; González-Bravo, R.; Loge, F.J. Water-energy-food security: A Nexus perspective of the current situation in Latin America and the Caribbean. Energy 2020, 194, 116824. [CrossRef]

6. Pollard, C.M.; Booth, S. Food Insecurity and Hunger in Rich Countries-It Is Time for Action against Inequality. Int. J. Environ. Res. Public Health 2019, 16, 1804. [CrossRef]

7. Abd-Elmabod, S.K.; Muñoz-Rojas, M.; Jordán, A.; Anaya-Romero, M.; Phillips, J.D.; Jones, L.; Zhang, Z.; Pereira, P.; Fleskens, L.; van der Ploeg, M.; et al. Climate change impacts on agricultural suitability and yield reduction in a Mediterranean region. Geoderma 2020, 374, 114453. [CrossRef]

8. Jat, M.L.; Bijay-Singh; Stirling, C.M.; Jat, H.S.; Tetarwal, J.P.; Jat, R.K.; Singh, R.; Lopez-Ridaura, S.; Shirsath, P.B. Chapter Four-Soil Processes and Wheat Cropping Under Emerging Climate Change Scenarios in South Asia. In Advances in Agronomy; Sparks, D.L., Ed.; Academic Press: Cambridge, MA, USA, 2018; Volume 148, pp. 111-171. ISBN 0065-2113.

9. Berners-Lee, M.; Kennelly, C.; Watson, R.; Hewitt, C.N. Current global food production is sufficient to meet human nutritional needs in 2050 provided there is radical societal adaptation. Elem. Sci. Anthr. 2018, 6. [CrossRef]

10. Thorne, S.J.; Hartley, S.E.; Maathuis, F.J.M. Is Silicon a Panacea for Alleviating Drought and Salt Stress in Crops? Front. Plant Sci. 2020, 11, 1221. [CrossRef]

11. Chaves, M.M.; Flexas, J.; Pinheiro, C. Photosynthesis under drought and salt stress: Regulation mechanisms from whole plant to cell. Ann. Bot. 2008, 103, 551-560. [CrossRef]

12. Al-Yasi, H.; Attia, H.; Alamer, K.; Hassan, F.; Ali, E.; Elshazly, S.; Siddique, K.H.; Hessini, K.; Esmat, F. Impact of drought on growth, photosynthesis, osmotic adjustment, and cell wall elasticity in Damask rose. Plant Physiol. Biochem. 2020, 150, 133-139. [CrossRef] [PubMed]

13. Anjum, S.A.; Ashraf, U.; Tanveer, M.; Khan, I.; Hussain, S.; Zohaib, A.; Abbas, F.; Saleem, M.F.; Wang, L. Drought tolerance in three maize cultivars is related to differential osmolyte accumulation, antioxidant defense system, and oxidative damage. Front. Plant Sci. 2017, 8, 69.

14. Wu, Y.-R.; Lin, Y.-C.; Chuang, H.-W. Laminarin modulates the chloroplast antioxidant system to enhance abiotic stress tolerance partially through the regulation of the defensin-like gene expression. Plant Sci. 2016, 247, 83-92. [CrossRef]

15. Arteaga, S.; Yabor, L.; Díez, M.J.; Prohens, J.; Boscaiu, M.; Vicente, O. The Use of Proline in Screening for Tolerance to Drought and Salinity in Common Bean (Phaseolus vulgaris L.) Genotypes. Agronomy 2020, 10, 817. [CrossRef]

16. Ashraf, M.; Foolad, M. Roles of glycine betaine and proline in improving plant abiotic stress resistance. Environ. Exp. Bot. 2007, 59, 206-216. [CrossRef]

17. Singh, M.; Kumar, J.; Singh, S.; Singh, V.P.; Prasad, S.M. Roles of osmoprotectants in improving salinity and drought tolerance in plants: A review. Rev. Environ. Sci. Bio Technol. 2015, 14, 407-426. [CrossRef]

18. García-García, A.L.; García-Machado, F.J.; Borges, A.A.; Morales-Sierra, S.; Boto, A.; Jiménez-Arias, D. Pure Organic Active Compounds Against Abiotic Stress: A Biostimulant Overview. Front. Plant Sci. 2020, 11, 1839. [CrossRef]

19. European Commission. Farm to Fork Strategy —For a Fair, Healthy and Environmentally-Friendly Food System; European Commission: Cardiff, UK, 2020.

20. EU Regulation. Regulation (EU) 2019/1009 of the European Parliament and of the Council of 5 June 2019 laying down rules on the making available on the market of EU fertilising products and amending Regulations (EC) No 1069/2009 and (EC) No 1107/2009 and (EC) No 1107/2009 and Repealing Regula 2019. Off. J. Eur. Union 2019, 62, 1-132.

21. Yakhin, O.I.; Lubyanov, A.A.; Yakhin, I.A.; Brown, P.H. Biostimulants in Plant Science: A Global Perspective. Front. Plant Sci. 2017, 7, 2049. [CrossRef]

22. du Jardin, P. Plant biostimulants: Definition, concept, main categories and regulation. Sci. Hortic. 2015, 196, 3-14. [CrossRef] 
23. Bulgari, R.; Franzoni, G.; Ferrante, A. Biostimulants Application in Horticultural Crops under Abiotic Stress Conditions. Agronomy 2019, 9, 306. [CrossRef]

24. Madende, M.; Hayes, M. Fish By-Product Use as Biostimulants: An Overview of the Current State of the Art, Including Relevant Legislation and Regulations within the EU and USA. Molecules 2020, 25, 1122. [CrossRef]

25. Bulgari, R.; Cocetta, G.; Trivellini, A.; Vernieri, P.; Ferrante, A. Biostimulants and crop responses: A review. Biol. Agric. Hortic. 2014, 31, 1-17. [CrossRef]

26. Colla, G.; Hoagland, L.; Ruzzi, M.; Cardarelli, M.; Bonini, P.; Canaguier, R.; Rouphael, Y. Biostimulant Action of Protein Hydrolysates: Unraveling Their Effects on Plant Physiology and Microbiome. Front. Plant Sci. 2017, 8, 2202. [CrossRef]

27. Ejaz, S.; Fahad, S.; Anjum, M.A.; Nawaz, A.; Naz, S.; Hussain, S.; Ahmad, S. Role of Osmolytes in the Mechanisms of Antioxidant Defense of Plants. Sustain. Agric. Rev. 2020, 39, 95-117. [CrossRef]

28. Slama, I.; Abdelly, C.; Bouchereau, A.; Flowers, T.; Savouré, A. Diversity, distribution and roles of osmoprotective compounds accumulated in halophytes under abiotic stress. Ann. Bot. 2015, 115, 433-447. [CrossRef] [PubMed]

29. Sharma, H.S.S.; Selby, C.; Carmichael, E.; McRoberts, C.; Rao, J.R.; Ambrosino, P.; Chiurazzi, M.; Pucci, M.; Martin, T. Physicochemical analyses of plant biostimulant formulations and characterisation of commercial products by instrumental techniques. Chem. Biol. Technol. Agric. 2016, 3, 3. [CrossRef]

30. Teixeira, W.F.; Fagan, E.B.; Soares, L.H.; Umburanas, R.C.; Reichardt, K.; Neto, D.D. Foliar and Seed Application of Amino Acids Affects the Antioxidant Metabolism of the Soybean Crop. Front. Plant Sci. 2017, 8, 327. [CrossRef]

31. Verbruggen, N.; Hermans, C. Proline accumulation in plants: A review. Amino Acids 2008, 35, 753-759. [CrossRef] [PubMed]

32. El Moukhtari, A.; Cabassa-Hourton, C.; Farissi, M.; Savouré, A. How Does Proline Treatment Promote Salt Stress Tolerance During Crop Plant Development? Front. Plant Sci. 2020, 11, 1127. [CrossRef] [PubMed]

33. Szabados, L.; Savouré, A. Proline: A multifunctional amino acid. Trends Plant Sci. 2010, 15, 89-97. [CrossRef] [PubMed]

34. Kavi Kishor, P.B.; Sreenivasulu, N. Is proline accumulation per se correlated with stress tolerance or is proline homeostasis a more critical issue? Plant Cell Environ. 2014, 37, 300-311. [CrossRef] [PubMed]

35. Kaur, G.; Asthir, B. Proline: A key player in plant abiotic stress tolerance. Biol. Plant. 2015, 59, 609-619. [CrossRef]

36. Székely, G.; Ábrahám, E.; Cséplő, Á.; Rigó, G.; Zsigmond, L.; Csiszár, J.; Ayaydin, F.; Strizhov, N.; Jásik, J.; Schmelzer, E.; et al. Duplicated P5CS genes of Arabidopsis play distinct roles in stress regulation and developmental control of proline biosynthesis. Plant J. 2008, 53, 11-28. [CrossRef]

37. Ben Ahmed, C.; Magdich, S.; Ben Rouina, B.; Sensoy, S.; Boukhris, M.; Ben Abdullah, F. Exogenous proline effects on water relations and ions contents in leaves and roots of young olive. Amino Acids 2010, 40, 565-573. [CrossRef] [PubMed]

38. Hayat, S.; Hayat, Q.; Alyemeni, M.N.; Wani, A.S.; Pichtel, J.; Ahmad, A. Role of proline under changing environments. Plant Signal. Behav. 2012, 7, 1456-1466. [CrossRef]

39. De Freitas, P.A.F.; De Carvalho, H.H.; Costa, J.H.; Miranda, R.D.S.; Saraiva, K.D.D.C.; De Oliveira, F.D.B.; Coelho, D.G.; Prisco, J.T.; Gomes-Filho, E. Salt acclimation in sorghum plants by exogenous proline: Physiological and biochemical changes and regulation of proline metabolism. Plant Cell Rep. 2019, 38, 403-416. [CrossRef] [PubMed]

40. Abdelaal, K.A.; El-Maghraby, L.M.; Elansary, H.; Hafez, Y.M.; Ibrahim, E.I.; El-Banna, M.; El-Esawi, M.; Elkelish, A. Treatment of Sweet Pepper with Stress Tolerance-Inducing Compounds Alleviates Salinity Stress Oxidative Damage by Mediating the Physio-Biochemical Activities and Antioxidant Systems. Agronomy 2019, 10, 26. [CrossRef]

41. Forde, B.G.; Lea, P.J. Glutamate in plants: Metabolism, regulation, and signalling. J. Exp. Bot. 2007, 58, 2339-2358. [CrossRef]

42. Qiu, X.-M.; Sun, Y.-Y.; Ye, X.-Y.; Li, Z.-G. Signaling Role of Glutamate in Plants. Front. Plant Sci. 2020, 10, 1743. [CrossRef]

43. Skopelitis, D.S.; Paranychianakis, N.V.; Paschalidis, K.A.; Pliakonis, E.D.; Delis, I.D.; Yakoumakis, D.I.; Kouvarakis, A.; Papadakis, A.K.; Stephanou, E.G.; Roubelakis-Angelakis, K.A. Abiotic Stress Generates ROS That Signal Expression of Anionic Glutamate Dehydrogenases to Form Glutamate for Proline Synthesis in Tobacco and Grapevine. Plant Cell 2006, 18, 2767-2781. [CrossRef]

44. Wang, Z.-Q.; Yuan, Y.-Z.; Ou, J.-Q.; Lin, Q.-H.; Zhang, C.-F. Glutamine synthetase and glutamate dehydrogenase contribute differentially to proline accumulation in leaves of wheat (Triticum aestivum) seedlings exposed to different salinity. J. Plant Physiol. 2007, 164, 695-701. [CrossRef]

45. Kan, C.-C.; Chung, T.-Y.; Wu, H.-Y.; Juo, Y.-A.; Hsieh, M.-H. Exogenous glutamate rapidly induces the expression of genes involved in metabolism and defense responses in rice roots. BMC Genom. 2017, 18, 186. [CrossRef]

46. Silveira, J.A.G.; Viégas, R.D.A.; Da Rocha, I.M.A.; Moreira, A.C.D.O.M.; Moreira, R.D.A.; Oliveira, J.T.A. Proline accumulation and glutamine synthetase activity are increased by salt-induced proteolysis in cashew leaves. J. Plant Physiol. 2003, 160, 115-123. [CrossRef]

47. La, V.H.; Lee, B.-R.; Islam, T.; Mamun, A.; Park, S.-H.; Bae, D.-W.; Kim, T.-H. Characterization of Glutamate-Mediated Hormonal Regulatory Pathway of the Drought Responses in Relation to Proline Metabolism in Brassica napus L. Plants 2020, 9, 512. [CrossRef]

48. Kinnersley, A.M.; Turano, F.J. Gamma Aminobutyric Acid (GABA) and Plant Responses to Stress. Crit. Rev. Plant Sci. 2000, 19, 479-509. [CrossRef]

49. Okuma, E.; Murakami, Y.; Shimoishi, Y.; Tada, M.; Murata, Y. Effects of exogenous application of proline and betaine on the growth of tobacco cultured cells under saline conditions. Soil Sci. Plant Nutr. 2004, 50, 1301-1305. [CrossRef]

50. Islam, M.M.; Hoque, A.; Okuma, E.; Banu, M.N.A.; Shimoishi, Y.; Nakamura, Y.; Murata, Y. Exogenous proline and glycinebetaine increase antioxidant enzyme activities and confer tolerance to cadmium stress in cultured tobacco cells. J. Plant Physiol. 2009, 166, 1587-1597. [CrossRef] 
51. Bor, M.; Turkan, I. Is there a room for GABA in ROS and RNS signalling? Environ. Exp. Bot. 2019, 161, 67-73. [CrossRef]

52. Shelp, B.J.; Mullen, R.T.; Waller, J.C. Compartmentation of GABA metabolism raises intriguing questions. Trends Plant Sci. 2012, 17, 57-59. [CrossRef] [PubMed]

53. Mirabella, R.; Rauwerda, H.; Struys, E.A.; Jakobs, C.; Triantaphylidès, C.; Haring, M.A.; Schuurink, R.C. The Arabidopsis her1 mutant implicates GABA in E-2-hexenal responsiveness. Plant J. 2007, 53, 197-213. [CrossRef] [PubMed]

54. Renault, H.; El Amrani, A.; Berger, A.; Mouille, G.; Soubigou-Taconnat, L.; Bouchereau, A.; Deleu, C. $\gamma$-Aminobutyric acid transaminase deficiency impairs central carbon metabolism and leads to cell wall defects during salt stress in Arabidopsis roots. Plant Cell Environ. 2013, 36, 1009-1018. [CrossRef]

55. Mekonnen, D.W.; Flügge, U.-I.; Ludewig, F. Gamma-aminobutyric acid depletion affects stomata closure and drought tolerance of Arabidopsis thaliana. Plant Sci. 2016, 245, 25-34. [CrossRef]

56. Sheteiwy, M.S.; Shao, H.; Qi, W.; Hamoud, Y.A.; Shaghaleh, H.; Khan, N.U.; Yang, R.; Tang, B. GABA-Alleviated Oxidative Injury Induced by Salinity, Osmotic Stress and their Combination by Regulating Cellular and Molecular Signals in Rice. Int. J. Mol. Sci. 2019, 20, 5709. [CrossRef]

57. Winter, G.; Todd, C.D.; Trovato, M.; Forlani, G.; Funck, D. Physiological implications of arginine metabolism in plants. Front. Plant Sci. 2015, 6, 534. [CrossRef] [PubMed]

58. Da Rocha, I.M.A.; Vitorello, V.A.; Silva, J.S.; Ferreira-Silva, S.L.; Viégas, R.A.; Silva, E.N.; Silveira, J.A.G. Exogenous ornithine is an effective precursor and the $\delta$-ornithine amino transferase pathway contributes to proline accumulation under high $\mathrm{N}$ recycling in salt-stressed cashew leaves. J. Plant Physiol. 2012, 169, 41-49. [CrossRef] [PubMed]

59. You, J.; Hu, H.; Xiong, L. An ornithine $\delta$-aminotransferase gene OsOAT confers drought and oxidative stress tolerance in rice. Plant Sci. 2012, 197, 59-69. [CrossRef]

60. Nasibi, F.; Yaghoobi, M.M.; Kalantari, K.M. Effect of exogenous arginine on alleviation of oxidative damage in tomato plant underwater stress. J. Plant Interact. 2011, 6, 291-296. [CrossRef]

61. Qados, A. Effect of arginine on growth, nutrient composition, yield and nutritional value of mung bean plants grown under salinity stress. Nat. Sci. 2010, 8, 30-42.

62. Peshev, D.; Vergauwen, R.; Moglia, A.; Hideg, É.; Van den Ende, W. Towards understanding vacuolar antioxidant mechanisms: A role for fructans? J. Exp. Bot. 2013, 64, 1025-1038. [CrossRef] [PubMed]

63. Hincha, D.K.; Zuther, E.; Heyer, A.G. The preservation of liposomes by raffinose family oligosaccharides during drying is mediated by effects on fusion and lipid phase transitions. Biochim. Biophys. Acta Biomembr. 2003, 1612, 172-177. [CrossRef]

64. Gómez-Ariza, J.; Campo, S.; Rufat, M.; Estopà, M.; Messeguer, J.; Segundo, B.S.; Coca, M. Sucrose-Mediated Priming of Plant Defense Responses and Broad-Spectrum Disease Resistance by Overexpression of the Maize Pathogenesis-Related PRms Protein in Rice Plants. Mol. Plant Microbe Interact. 2007, 20, 832-842. [CrossRef] [PubMed]

65. Koyro, H.-W.; Ahmad, P.; Geissler, N. Abiotic Stress Responses in Plants: An Overview. In Environmental Adaptations and Stress Tolerance of Plants in the Era of Climate Change; Springer International Publishing: New York, NY, USA, 2011; pp. 1-28.

66. Thalmann, M.; Santelia, D. Starch as a determinant of plant fitness under abiotic stress. New Phytol. 2017, 214, 943-951. [CrossRef]

67. Livingston, D.P.; Hincha, D.K.; Heyer, A.G. Fructan and its relationship to abiotic stress tolerance in plants. Cell. Mol. Life Sci. 2009, 66, 2007-2023. [CrossRef]

68. Sun, X.; Zong, Y.; Yang, S.; Wang, L.; Gao, J.; Wang, Y.; Liu, B.; Zhang, H. A fructan: The fructan 1-fructosyl-transferase gene from Helianthus tuberosus increased the PEG-simulated drought stress tolerance of tobacco. Hereditas 2020, 157, 1-8. [CrossRef] [PubMed]

69. Elsayed, A.I.; Rafudeen, M.S.; Golldack, D. Physiological aspects of raffinose family oligosaccharides in plants: Protection against abiotic stress. Plant Biol. 2014, 16, 1-8. [CrossRef] [PubMed]

70. Sami, F.; Yusuf, M.; Faizan, M.; Faraz, A.; Hayat, S. Role of sugars under abiotic stress. Plant Physiol. Biochem. 2016, 109 , 54-61. [CrossRef]

71. Almodares, A.; Hadi, M.R.; Dosti, B. The Effects of Salt Stress on Growth Parameters and Carbohydrates Contents in Sweet Sorghum. Res. J. Environ. Sci. 2008, 2, 298-304.

72. Hu, M.; Shi, Z.; Zhang, Z.; Zhang, Y.; Li, H. Effects of exogenous glucose on seed germination and antioxidant capacity in wheat seedlings under salt stress. Plant Growth Regul. 2012, 68, 177-188. [CrossRef]

73. Hellmann, H.; Funck, D.; Rentsch, D.; Frommer, W.B. Hypersensitivity of an Arabidopsis sugar signaling mutant toward exogenous proline application. Plant Physiol. 2000, 122, 357-368. [CrossRef] [PubMed]

74. Iordachescu, M.; Imai, R. Trehalose Biosynthesis in Response to Abiotic Stresses. J. Integr. Plant Biol. 2008, 50, 1223-1229. [CrossRef] [PubMed]

75. Krasensky, J.; Jonak, C. Drought, salt, and temperature stress-induced metabolic rearrangements and regulatory networks. J. Exp. Bot. 2012, 63, 1593-1608. [CrossRef]

76. Ge, L.-F.; Chao, D.-Y.; Shi, M.; Zhu, M.-Z.; Gao, J.-P.; Lin, H.-X. Overexpression of the trehalose-6-phosphate phosphatase gene OsTPP1 confers stress tolerance in rice and results in the activation of stress responsive genes. Planta 2008, 228, 191-201. [CrossRef] [PubMed]

77. Fernandez, O.; Béthencourt, L.; Quero, A.; Sangwan, R.S.; Clément, C. Trehalose and plant stress responses: Friend or foe? Trends Plant Sci. 2010, 15, 409-417. [CrossRef] [PubMed] 
78. Samadi, S.; Habibi, G.; Vaziri, A. Exogenous trehalose alleviates the inhibitory effects of salt stress in strawberry plants. Acta Physiol. Plant. 2019, 41, 112. [CrossRef]

79. Biswas, J.C.; Naher, U.A. Soil nutrient stress and rice production in Bangladesh. In Advances in Rice Research for Abiotic Stress Tolerance; Hasanuzzaman, M., Fujita, M., Nahar, K., Biswas, J.K., Eds.; Woodhead Publishing: Cambridge, UK, 2019 ; pp. 431-445. ISBN 9780128143322.

80. Wu, T.; Wang, Y.; Zheng, Y.; Fei, Z.; Dandekar, A.M.; Xu, K.; Han, Z.; Cheng, L. Suppressing Sorbitol Synthesis Substantially Alters the Global Expression Profile of Stress Response Genes in Apple (Malus domestica) Leaves. Plant Cell Physiol. 2015, 56, 1748-1761. [CrossRef]

81. Loewus, F.A.; Murthy, P.P.N. myo-Inositol metabolism in plants. Plant Sci. 2000, 150, 1-19. [CrossRef]

82. Taji, T.; Takahashi, S.; Shinozaki, K. Inositols and Their Metabolites in Abiotic and Biotic Stress Responses. In Cholesterol Binding and Cholesterol Transport Proteins; Springer International Publishing: New York, NY, USA, 2006; Volume 39, pp. $239-264$.

83. Mukherjee, R.; Mukherjee, A.; Bandyopadhyay, S.; Mukherjee, S.; Sengupta, S.; Ray, S.; Majumder, A.L. Selective manipulation of the inositol metabolic pathway for induction of salt-tolerance in indica rice variety. Sci. Rep. 2019, 9, 1-16. [CrossRef] [PubMed]

84. Yildizli, A.; Cevik, S.; Ünyayar, S. Effects of exogenous myo-inositol on leaf water status and oxidative stress of Capsicum annuum under drought stress. Acta Physiol. Plant. 2018, 40, 122. [CrossRef]

85. Patel, T.K.; Williamson, J.D. Mannitol in Plants, Fungi, and Plant-Fungal Interactions. Trends Plant Sci. 2016, $21,486-497$. [CrossRef]

86. Abebe, T.; Guenzi, A.C.; Martin, B.; Cushman, J.C. Tolerance of Mannitol-Accumulating Transgenic Wheat to Water Stress and Salinity. Plant Physiol. 2003, 131, 1748-1755. [CrossRef]

87. Seckin, B.; Sekmen, A.H.; Türkan, I. An Enhancing Effect of Exogenous Mannitol on the Antioxidant Enzyme Activities in Roots of Wheat Under Salt Stress. J. Plant Growth Regul. 2009, 28, 12-20. [CrossRef]

88. Kaya, C.; Sonmez, O.; Aydemir, S.; Ashraf, M.; Dikilitas, M. Exogenous application of mannitol and thiourea regulates plant growth and oxidative stress responses in salt-stressed maize (Zea mays L.). J. Plant Interact. 2013, 8, 234-241. [CrossRef]

89. Ashraf, M.; Harris, P. Potential biochemical indicators of salinity tolerance in plants. Plant Sci. 2004, 166, 3-16. [CrossRef]

90. Kumar, V.; Shriram, V.; Hoque, T.S.; Hasan, M.M.; Burritt, D.J.; Hossain, M.A. Glycinebetaine-Mediated Abiotic Oxidative-Stress Tolerance in Plants: Physiological and Biochemical Mechanisms. In Stress Signaling in Plants: Genomics and Proteomics Perspective; Sarwat, M., Ahmad, A., Abdin, M.Z., Ibrahim, M.M., Eds.; Springer International Publishing: Cham, Germany, 2017; Volume 2, pp. 111-133. ISBN 978-3-319-42183-4.

91. Moghaieb, R.E.A.; Tanaka, N.; Saneoka, H.; Hussein, H.A.; Yousef, S.S.; Ewada, M.A.-F.; Aly, M.A.M.; Fujita, K. Expression of betaine aldehyde dehydrogenase gene in transgenic tomato hairy roots leads to the accumulation of glycine betaine and contributes to the maintenance of the osmotic potential under salt stress. Soil Sci. Plant Nutr. 2000, 46, 873-883. [CrossRef]

92. Ahmad, R.; Kim, M.D.; Back, K.-H.; Kim, H.-S.; Lee, H.-S.; Kwon, S.-Y.; Murata, N.; Chung, W.-I.; Kwak, S.-S. Stress-induced expression of choline oxidase in potato plant chloroplasts confers enhanced tolerance to oxidative, salt, and drought stresses. Plant Cell Rep. 2007, 27, 687-698. [CrossRef]

93. Wang, G.P.; Zhang, X.Y.; Li, F.; Luo, Y.; Wang, W. Erratum to: Overaccumulation of glycine betaine enhances tolerance to drought and heat stress in wheat leaves in the protection of photosynthesis. Photosynthetica 2010, 48, 302. [CrossRef]

94. Pei, L.; Li, H.; Zhou, Y.; Li, W.; Jiang, Y.; Li, H. Exogenous Glycinebetaine Application Contributes to Abiotic Stress Tolerance in Maize. J. Plant Biol. 2020, 1-13. [CrossRef]

95. Trinchant, J.-C.; Boscari, A.; Spennato, G.; Van De Sype, G.; Le Rudulier, D. Proline Betaine Accumulation and Metabolism in Alfalfa Plants under Sodium Chloride Stress. Exploring Its Compartmentalization in Nodules. Plant Physiol. 2004, 135, 1583-1594. [CrossRef] [PubMed]

96. Bashir, A.; Hoffmann, T.; Kempf, B.; Xie, X.; Smits, S.H.J.; Bremer, E. Plant-derived compatible solutes proline betaine and betonicine confer enhanced osmotic and temperature stress tolerance to Bacillus subtilis. Microbiology 2014, 160, 2283-2294. [CrossRef]

97. Hanson, A.D.; Rathinasabapathi, B.; Rivoal, J.; Burnet, M.; Dillon, M.O.; Gage, D.A. Osmoprotective compounds in the Plumbaginaceae: A natural experiment in metabolic engineering of stress tolerance. Proc. Natl. Acad. Sci. USA 1994, 91, 306-310. [CrossRef]

98. Hanson, A.D.; Rathinasabapathi, B.; Chamberlin, B.; Gage, D.A. Comparative Physiological Evidence that $\beta$-Alanine Betaine and Choline-O-Sulfate Act as Compatible Osmolytes in Halophytic Limonium Species. Plant Physiol. 1991, 97, 1199-1205. [CrossRef]

99. Otte, M.L.; Wilson, G.; Morris, J.T.; Moran, B.M. Dimethylsulphoniopropionate (DMSP) and related compounds in higher plants. J. Exp. Bot. 2004, 55, 1919-1925. [CrossRef]

100. Kirst, G.O. Osmotic Adjustment in Phytoplankton and MacroAlgae. In Biological and Environmental Chemistry of DMSP and Related Sulfonium Compounds; Springer International Publishing: New York, NY, USA, 1996; pp. 121-129.

101. Páldi, K.; Rácz, I.; Szigeti, Z.; Rudnóy, S. S-methylmethionine alleviates the cold stress by protection of the photosynthetic apparatus and stimulation of the phenylpropanoid pathway. Biol. Plant. 2014, 58, 189-194. [CrossRef]

102. Fodorpataki, L.; Molnar, K.; Tompa, B.; Plugaru, S.R.C. Priming with Vitamin U Enhances Cold Tolerance of Lettuce (Lactuca sativa L.). Not. Bot. Horti Agrobot. ClujNapoca 2019, 47, 592-598. [CrossRef]

103. Sequera-Mutiozabal, M.; Antoniou, C.; Tiburcio, A.F.; Alcázar, R.; Fotopoulos, V. Polyamines: Emerging Hubs Promoting Drought and Salt Stress Tolerance in Plants. Curr. Mol. Biol. Rep. 2017, 3, 28-36. [CrossRef] 
104. Borges, A.A.; Jiménez-Arias, D.; Expósito-Rodríguez, M.; Sandalio, L.M.; Pérez, J.A. Priming crops against biotic and abiotic stresses: MSB as a tool for studying mechanisms. Front. Plant Sci. 2014, 5, 642. [CrossRef]

105. Yin, L.; Wang, P.; Li, M.; Ke, X.; Li, C.; Liang, D.; Wu, S.; Ma, X.; Li, C.; Zou, Y.; et al. Exogenous melatonin improves Malus resistance to Marssonina apple blotch. J. Pineal Res. 2013, 54, 426-434. [CrossRef]

106. Sharma, A.; Zheng, B. Melatonin Mediated Regulation of Drought Stress: Physiological and Molecular Aspects. Plants 2019, 8, 190. [CrossRef]

107. Groppa, M.D.; Benavides, M.P. Polyamines and abiotic stress: Recent advances. Amino Acids 2007, 34, 35-45. [CrossRef] [PubMed]

108. Kusano, T.; Yamaguchi, K.; Berberich, T.; Takahashi, Y. Advances in polyamine research in Polyamine Research in 2007. J. Plant Res. 2007, 120, 345-350. [CrossRef] [PubMed]

109. Gill, S.S.; Tuteja, N. Polyamines and abiotic stress tolerance in plants. Plant Signal. Behav. 2010, 5, 26-33. [CrossRef] [PubMed]

110. Hussain, S.S.; Ali, M.; Ahmad, M.; Siddique, K.H. Polyamines: Natural and engineered abiotic and biotic stress tolerance in plants. Biotechnol. Adv. 2011, 29, 300-311. [CrossRef] [PubMed]

111. Carbonell, J.; Blázquez, M.A. Regulatory mechanisms of polyamine biosynthesis in plants. Genes Genom. 2009, 31, 107-118. [CrossRef]

112. Shu, S.; Guo, S.-R.; Sun, J.; Yuan, L.-Y. Effects of salt stress on the structure and function of the photosynthetic apparatus in Cucumis sativus and its protection by exogenous putrescine. Physiol. Plant. 2012, 146, 285-296. [CrossRef] [PubMed]

113. Zhang, R.H.; Li, J.; Guo, S.R.; Tezuka, T. Effects of exogenous putrescine on gas-exchange characteristics and chlorophyll fluorescence of NaCl-stressed cucumber seedlings. Photosynth. Res. 2009, 100, 155-162. [CrossRef] [PubMed]

114. Li, L.; Gu, W.; Li, C.; Li, W.; Li, C.; Li, J.; Wei, S. Exogenous spermidine improves drought tolerance in maize by enhancing the antioxidant defence system and regulating endogenous polyamine metabolism. Crop. Pasture Sci. 2018, 69, 1076. [CrossRef]

115. Yi, Z.; Li, S.; Liang, Y.; Zhao, H.; Hou, L.; Yu, S.; Ahammed, G.J. Effects of Exogenous Spermidine and Elevated $\mathrm{CO}_{2}$ on Physiological and Biochemical Changes in Tomato Plants Under Iso-osmotic Salt Stress. J. Plant Growth Regul. 2018, 37, 1222-1234. [CrossRef]

116. Li, J.; Hu, L.; Zhang, L.; Pan, X.; Hu, X. Exogenous spermidine is enhancing tomato tolerance to salinity-alkalinity stress by regulating chloroplast antioxidant system and chlorophyll metabolism. BMC Plant Biol. 2015, 15, 303. [CrossRef] [PubMed]

117. Li, L.; Gu, W.; Li, J.; Li, C.; Xie, T.; Qu, D.; Meng, Y.; Li, C.; Wei, S. Exogenously applied spermidine alleviates photosynthetic inhibition under drought stress in maize (Zea mays L.) seedlings associated with changes in endogenous polyamines and phytohormones. Plant Physiol. Biochem. 2018, 129, 35-55. [CrossRef]

118. Farooq, M.; Wahid, A.; Lee, D.-J. Exogenously applied polyamines increase drought tolerance of rice by improving leaf water status, photosynthesis and membrane properties. Acta Physiol. Plant. 2009, 31, 937-945. [CrossRef]

119. Shinohara, S.; Okamoto, T.; Motose, H.; Takahashi, T. Salt hypersensitivity is associated with excessive xylem development in a thermospermine-deficient mutant ofArabidopsis thaliana. Plant J. 2019, 100, 374-383. [CrossRef] [PubMed]

120. Liang, Y.; Nikolic, M.; Bélanger, R.; Gong, H.; Song, A. Silicon in Agriculture; Springer International Publishing: New York, NY, USA, 2015.

121. Ma, J.F.; Yamaji, N. Silicon uptake and accumulation in higher plants. Trends Plant Sci. 2006, 11, 392-397. [CrossRef] [PubMed]

122. Hoffmann, J.; Berni, R.; Hausman, J.-F.; Guerriero, G. A Review on the Beneficial Role of Silicon against Salinity in NonAccumulator Crops: Tomato as a Model. Biomolecules 2020, 10, 1284. [CrossRef] [PubMed]

123. Ma, D.; Sun, D.; Wang, C.; Qin, H.; Ding, H.; Li, Y.; Guo, T. Silicon Application Alleviates Drought Stress in Wheat Through Transcriptional Regulation of Multiple Antioxidant Defense Pathways. J. Plant Growth Regul. 2015, 35, 1-10. [CrossRef]

124. Zuccarini, P. Effects of silicon on photosynthesis, water relations and nutrient uptake of Phaseolus vulgaris under $\mathrm{NaCl}$ stress. Biol. Plant. 2008, 52, 157-160. [CrossRef]

125. Ahmad, M.; El-Saeid, M.H.; Akram, M.A.; Ahmad, H.R.; Haroon, H.; Hussain, A. Silicon fertilization-A tool to boost up drought tolerance in wheat (Triticum aestivum L.) crop for better yield. J. Plant Nutr. 2016, 39, 1283-1291. [CrossRef]

126. Laifa, I.; Hajji, M.; Farhat, N.; Elkhouni, A.; Smaoui, A.; M’Nif, A.; Hamzaoui, A.H.; Savouré, A.; Abdelly, C.; Zorrig, W. Beneficial Effects of Silicon (Si) on Sea Barley (Hordeum marinum Huds.) under Salt Stress. Silicon 2020, 1-17. [CrossRef]

127. El-Mageed, T.A.A.; Shaaban, A.; El-Mageed, S.A.A.; Semida, W.M.; Rady, M.O.A. Silicon defensive role in maize (Zea mays L.) against drought stress and metals-contaminated irrigation water. Silicon 2020, 1-12. [CrossRef]

128. Ali, L.G.; Nulit, R.; Ibrahim, M.H.; Yien, C.Y.S. Enhancement of germination and early seedling growth of rice (Oryza sativa) var. FARO44 by seed priming under normal and drought stressed conditions. J. Plant Nutr. 2020, 43, 1579-1593. [CrossRef]

129. Behboudi, F.; Tahmasebi Sarvestani, Z.; Zaman Kassaee, M.; Modares Sanavi, S.A.M.; Sorooshzadeh, A. Improving growth and yield of wheat under drought stress via application of SiO2 nanoparticles. J. Agric. Sci. Technol. 2018, 20, 1479-1492.

130. Alam, A.; Hariyanto, B.; Ullah, H.; Salin, K.R.; Datta, A. Effects of Silicon on Growth, Yield and Fruit Quality of Cantaloupe under Drought Stress. Silicon 2020, 1-10. [CrossRef]

131. Luyckx, M.; Hausman, J.-F.; Lutts, S.; Guerriero, G. Silicon and Plants: Current Knowledge and Technological Perspectives. Front. Plant Sci. 2017, 8, 411. [CrossRef]

132. Zhu, Y.; Gong, H. Beneficial effects of silicon on salt and drought tolerance in plants. Agron. Sustain. Dev. 2014, 34, 455-472. [CrossRef]

133. Ma, J.; Miyake, Y.; Takahashi, E. Chapter 2 Silicon as a beneficial element for crop plants. In Silicon in Agriculture; Elsevier BV: Amsterdam, The Netherlands, 2001; Volume 8, pp. 17-39. 
134. Shi, Y.; Wang, Y.; Flowers, T.J.; Gong, H. Silicon decreases chloride transport in rice (Oryza sativa L.) in saline conditions. J. Plant Physiol. 2013, 170, 847-853. [CrossRef] [PubMed]

135. Manzotti, P.; De Nisi, P.; Zocchi, G. Vitamin K in Plants. Funct. Plant Sci. Biotechnol. 2008, 2, $29-35$.

136. Borges, A.A.; Dobon, A.; Expósito-Rodríguez, M.; Jiménez-Arias, D.; Borges-Pérez, A.; Casañas-Sánchez, V.; Pérez, J.A.; Luis, J.C.; Tornero, P. Molecular analysis of menadione-induced resistance against biotic stress in Arabidopsis. Plant Biotechnol. J. 2009, 7, 744-762. [CrossRef] [PubMed]

137. Jo, Y.S.; Bin Park, H.; Kim, J.Y.; Choi, S.M.; Lee, D.S.; Kim, D.H.; Lee, Y.H.; Park, C.-J.; Jeun, Y.-C.; Hong, J.K. Menadione Sodium Bisulfite-Protected Tomato Leaves against Grey Mould via Antifungal Activity and Enhanced Plant Immunity. Plant Pathol. J. 2020, 36, 335-345. [PubMed]

138. Jiménez-Arias, D.; Perez, J.A.; Luis, J.C.; Martín-Rodríguez, V.; Valdés-González, F.; Borges, A.A. Treating seeds in menadione sodium bisulphite primes salt tolerance in Arabidopsis by inducing an earlier plant adaptation. Environ. Exp. Bot. 2015, 109, 23-30. [CrossRef]

139. Jiménez-Arias, D.; García-Machado, F.J.; Morales-Sierra, S.; Suárez, E.; Pérez, J.A.; Luis, J.C.; Garrido-Orduña, C.; Herrera, A.J.; Valdés, F.; Sandalio, L.M.; et al. Menadione sodium bisulphite (MSB): Beyond seed-soaking. Root pretreatment with MSB primes salt stress tolerance in tomato plants. Environ. Exp. Bot. 2019, 157, 161-170. [CrossRef]

140. Ashraf, M.A.; Asma, H.F.; Iqbal, M. Exogenous menadione sodium bisulfite mitigates specific ion toxicity and oxidative damage in salinity-stressed okra (Abelmoschus esculentus Moench). Acta Physiol. Plant. 2019, 41, 187. [CrossRef]

141. Jiménez-Arias, D.; Borges, A.A.; Luis, J.C.; Valdés, F.; Sandalio, L.M.; Perez, J.A. Priming effect of menadione sodium bisulphite against salinity stress in Arabidopsis involves epigenetic changes in genes controlling proline metabolism. Environ. Exp. Bot. 2015, 120, 23-30. [CrossRef]

142. Venegas-Molina, J.; Proietti, S.; Pollier, J.; Orozco-Freire, W.; Ramirez-Villacis, D.; Leon-Reyes, A. Induced tolerance to abiotic and biotic stresses of broccoli and Arabidopsis after treatment with elicitor molecules. Sci. Rep. 2020, 10, 1-17. [CrossRef]

143. Rasheed, R.; Ashraf, M.A.; Kamran, S.; Iqbal, M.; Hussain, I. Menadione sodium bisulphite mediated growth, secondary metabolism, nutrient uptake and oxidative defense in okra (Abelmoschus esculentus Moench) under cadmium stress. J. Hazard. Mater. 2018, 360, 604-614. [CrossRef]

144. Ashraf, M.A.; Rasheed, R.; Zafar, S.; Iqbal, M.; Saqib, Z.A. Menadione sodium bisulfite neutralizes chromium phytotoxic effects in okra by regulating cytosolutes, lipid peroxidation, antioxidant system and metal uptake. Int. J. Phytoremediat. 2020, 1-11. [CrossRef] [PubMed]

145. Arnao, M.B.; Hernández-Ruiz, J. Melatonin: Plant growth regulator and/or biostimulator during stress? Trends Plant Sci. 2014, 19, 789-797. [CrossRef] [PubMed]

146. Fan, J.; Xie, Y.; Zhang, Z.; Chen, L. Melatonin: A Multifunctional Factor in Plants. Int. J. Mol. Sci. 2018, 19, 1528. [CrossRef] [PubMed]

147. Back, K. Melatonin metabolism, signaling and possible roles in plants. Plant J. 2020. [CrossRef]

148. Zhang, N.; Sun, Q.; Zhang, H.; Cao, Y.; Weeda, S.; Ren, S.; Guo, Y.-D. Roles of melatonin in abiotic stress resistance in plants. J. Exp. Bot. 2015, 66, 647-656. [CrossRef]

149. Wang, L.; Zhao, Y.; Reiter, R.J.; He, C.; Liu, G.; Lei, Q.; Zuo, B.; Zheng, X.D.; Li, Q.; Kong, J. Changes in melatonin levels in transgenic 'Micro-Tom' tomato overexpressing ovine AANAT and ovine HIOMT genes. J. Pineal Res. 2014, 56, 134-142. [CrossRef] [PubMed]

150. Ren, J.; Ye, J.; Yin, L.; Li, G.; Deng, X.; Wang, S. Exogenous Melatonin Improves Salt Tolerance by Mitigating Osmotic, Ion, and Oxidative Stresses in Maize Seedlings. Agronomy 2020, 10, 663. [CrossRef]

151. Xia, H.; Ni, Z.; Hu, R.; Lin, L.; Deng, H.; Wang, J.; Tang, Y.; Sun, G.; Wang, X.; Li, H.; et al. Melatonin Alleviates Drought Stress by a Non-Enzymatic and Enzymatic Antioxidative System in Kiwifruit Seedlings. Int. J. Mol. Sci. 2020, 21, 852. [CrossRef]

152. Lee, H.-J.; Back, K. 2-Hydroxymelatonin promotes the resistance of rice plant to multiple simultaneous abiotic stresses (combined cold and drought). J. Pineal Res. 2016, 61, 303-316. [CrossRef]

153. Battacharyya, D.; Babgohari, M.Z.; Rathor, P.; Prithiviraj, B. Seaweed extracts as biostimulants in horticulture. Sci. Hortic. 2015, 196, 39-48. [CrossRef]

154. Sharma, H.S.S.; Fleming, C.C.; Selby, C.; Rao, J.R.; Martin, T. Plant biostimulants: A review on the processing of macroalgae and use of extracts for crop management to reduce abiotic and biotic stresses. Environ. Boil. Fishes 2013, 26, 465-490. [CrossRef]

155. Goñi, O.; Fort, A.; Quille, P.; McKeown, P.C.; Spillane, C.; O'Connell, S. Comparative Transcriptome Analysis of TwoAscophyllum nodosumExtract Biostimulants: Same Seaweed but Different. J. Agric. Food Chem. 2016, 64, 2980-2989. [CrossRef] [PubMed]

156. Nair, P.; Kandasamy, S.; Zhang, J.; Ji, X.; Kirby, C.; Benkel, B.; Hodges, M.D.; Critchley, A.T.; Hiltz, D.; Prithiviraj, B. Transcriptional and metabolomic analysis of Ascophyllum nodosum mediated freezing tolerance in Arabidopsis thaliana. BMC Genom. 2012, 13, 643. [CrossRef]

157. Carillo, P.; Ciarmiello, L.F.; Woodrow, P.; Corrado, G.; Chiaiese, P.; Rouphael, Y. Enhancing Sustainability by Improving Plant Salt Tolerance through Macro- and Micro-Algal Biostimulants. Biology 2020, 9, 253. [CrossRef]

158. Michalak, I.; Chojnacka, K.; Dmytryk, A.; Wilk, R.; Gramza, M.; Rój, E. Evaluation of Supercritical Extracts of Algae as Biostimulants of Plant Growth in Field Trials. Front. Plant Sci. 2016, 7, 1591. [CrossRef] [PubMed]

159. Hai, N.N.; Chuong, N.N.; Tu, N.H.C.; Kisiala, A.; Hoang, X.L.T.; Thao, N.P. Role and Regulation of Cytokinins in Plant Response to Drought Stress. Plants 2020, 9, 422. [CrossRef] 
160. Shukla, P.S.; Mantin, E.G.; Adil, M.; Bajpai, S.; Critchley, A.T.; Prithiviraj, B. Ascophyllum nodosum-Based Biostimulants: Sustainable Applications in Agriculture for the Stimulation of Plant Growth, Stress Tolerance, and Disease Management. Front. Plant Sci. 2019, 10, 655. [CrossRef] [PubMed]

161. Goñi, O.; Quille, P.; O'Connell, S. Ascophyllum nodosum extract biostimulants and their role in enhancing tolerance to drought stress in tomato plants. Plant Physiol. Biochem. 2018, 126, 63-73. [CrossRef]

162. Bonomelli, C.; Celis, V.; Lombardi, G.; Mártiz, J. Salt Stress Effects on Avocado (Persea americana Mill.) Plants with and without Seaweed Extract (Ascophyllum nodosum) Application. Agronomy 2018, 8, 64. [CrossRef]

163. Di Stasio, E.; Van Oosten, M.J.; Silletti, S.; Raimondi, G.; Dell'Aversana, E.; Carillo, P.; Maggio, A. Ascophyllum nodosum-based algal extracts act as enhancers of growth, fruit quality, and adaptation to stress in salinized tomato plants. J. Appl. Phycol. 2018, 30, 2675-2686. [CrossRef]

164. Norrie, J. Ascophyllum nodosum extracts: Gifts from Poseidon to Theoi Georgikoi (the Greek gods of agriculture). Acta Hortic. 2016, 1148, 1-12. [CrossRef]

165. Stirk, W.A.; Tarkowská, D.; Turečová, V.; Strnad, M.; Van Staden, J. Abscisic acid, gibberellins and brassinosteroids in Kelpak ${ }^{\circledR}$, a commercial seaweed extract made from Ecklonia maxima. Environ. Boil. Fishes 2013, 26, 561-567. [CrossRef]

166. Rouphael, Y.; De Micco, V.; Arena, C.; Raimondi, G.; Colla, G.; De Pascale, S. Effect of Ecklonia maxima seaweed extract on yield, mineral composition, gas exchange, and leaf anatomy of zucchini squash grown under saline conditions. Environ. Boil. Fishes 2017, 29, 459-470. [CrossRef]

167. Mattner, S.W.; Milinkovic, M.; Arioli, T. Increased growth response of strawberry roots to a commercial extract from Durvillaea potatorum and Ascophyllum nodosum. Environ. Boil. Fishes 2018, 30, 2943-2951. [CrossRef] [PubMed]

168. Julia, I.; Oscar, M.; Analía, L.; Guilherme, J.Z.; Virginia, L. Biofertilization with Macrocystis pyrifera algae extracts combined with PGPR-enhanced growth in Lactuca sativa seedlings. Environ. Boil. Fishes 2020, 32, 4361-4371. [CrossRef]

169. Ronga, D.; Biazzi, E.; Parati, K.; Carminati, D.; Carminati, E.; Tava, A. Microalgal Biostimulants and Biofertilisers in Crop Productions. Agronomy 2019, 9, 192. [CrossRef]

170. Colla, G.; Rouphael, Y. Microalgae: New Source of Plant Biostimulants. Agronomy 2020, 10, 1240. [CrossRef]

171. Kumar, A.; Verma, J.P. Does plant-Microbe interaction confer stress tolerance in plants: A review? Microbiol. Res. 2018, 207, 41-52. [CrossRef]

172. Van Oosten, M.J.; Pepe, O.; De Pascale, S.; Silletti, S.; Maggio, A. The role of biostimulants and bioeffectors as alleviators of abiotic stress in crop plants. Chem. Biol. Technol. Agric. 2017, 4, 5. [CrossRef]

173. Naamala, J.; Smith, D.L. Relevance of Plant Growth Promoting Microorganisms and Their Derived Compounds, in the Face of Climate Change. Agronomy 2020, 10, 1179. [CrossRef]

174. Yang, J.; Kloepper, J.W.; Ryu, C.-M. Rhizosphere bacteria help plants tolerate abiotic stress. Trends Plant Sci. 2009, 14, 1-4. [CrossRef]

175. Turetschek, R.; Staudinger, C.; Wienkoop, S. Rhizobial symbiosis influences response to early salt and drought stress of the Medicago truncatula root proteome. In The Model Legume Medicago Truncatula; Wiley: Hoboken, NI, USA, 2019 ; pp. $253-260$.

176. Zaidi, N.W.; Dar, M.H.; Singh, S.; Singh, U. Trichoderma Species as Abiotic Stress Relievers in Plants. Biotechnol. Biol. Trichoderma 2014, 515-525. [CrossRef]

177. Zhang, S.; Gan, Y.; Xu, B. Application of Plant-Growth-Promoting Fungi Trichoderma longibrachiatum T6 Enhances Tolerance of Wheat to Salt Stress through Improvement of Antioxidative Defense System and Gene Expression. Front. Plant Sci. 2016, 7, 1405. [CrossRef]

178. Zhang, F.; Wang, Y.; Liu, C.; Chen, F.; Ge, H.; Tian, F.; Yang, T.; Ma, K.; Zhang, Y. Trichoderma harzianum mitigates salt stress in cucumber via multiple responses. Ecotoxicol. Environ. Saf. 2019, 170, 436-445. [CrossRef]

179. Guler, N.S.; Pehlivan, N.; Karaoglu, S.A.; Guzel, S.; Bozdeveci, A. Trichoderma atroviride ID20G inoculation ameliorates drought stress-induced damages by improving antioxidant defence in maize seedlings. Acta Physiol. Plant. 2016, 38, 1-9. [CrossRef]

180. Shukla, N.; Awasthi, R.; Rawat, L.; Kumar, J. Biochemical and physiological responses of rice (Oryza sativa L.) as influenced by Trichoderma harzianum under drought stress. Plant Physiol. Biochem. 2012, 54, 78-88. [CrossRef]

181. Miransari, M.; Smith, D. Alleviating salt stress on soybean (Glycine max (L.) Merr.)—Bradyrhizobium japonicum symbiosis, using signal molecule genistein. Eur. J. Soil Biol. 2009, 45, 146-152. [CrossRef]

182. Cesari, A.B.; Paulucci, N.S.; López-Gómez, M.; Hidalgo-Castellanos, J.; Plá, C.L.; Dardanelli, M.S. Performance of Bradyrhizobium and Bradyrhizobium-Azospirillum in Alleviating the Effects of Water-Restrictive Conditions During the Early Stages of Arachis hypogaea Growth. J. Plant Growth Regul. 2019, 38, 1362-1374. [CrossRef]

183. Shirinbayan, S.; Khosravi, H.; Malakouti, M.J. Alleviation of drought stress in maize (Zea mays) by inoculation with Azotobacter strains isolated from semi-arid regions. Appl. Soil Ecol. 2019, 133, 138-145. [CrossRef]

184. Viscardi, S.; Ventorino, V.; Duran, P.; Maggio, A.; De Pascale, S.; Mora, M.; Pepe, O. Assessment of plant growth promoting activities and abiotic stress tolerance of Azotobacter chroococcum strains for a potential use in sustainable agriculture. J. Soil Sci. Plant Nutr. 2016. [CrossRef]

185. El-Esawi, M.A.; Al-Ghamdi, A.A.; Ali, H.M.; Alayafi, A.A. Azospirillum lipoferum FK1 confers improved salt tolerance in chickpea (Cicer arietinum L.) by modulating osmolytes, antioxidant machinery and stress-related genes expression. Environ. Exp. Bot. 2019, 159, 55-65. [CrossRef] 
186. Vacheron, J.; Renoud, S.; Muller, D.; Babalola, O.O.; Prigent-Combaret, C. Alleviation of Abiotic and Biotic Stresses in Plants by Azospirillum. In Handbook for Azospirillum; Springer International Publishing: New York, NY, USA, 2015; pp. $333-365$.

187. Sarma, R.K.; Saikia, R. Alleviation of drought stress in mung bean by strain Pseudomonas aeruginosa GGRJ21. Plant Soil 2014, 377, 111-126. [CrossRef]

188. He, Y.; Wu, Z.; Tu, L.; Shan, C. Effect of encapsulated pseudomonas putida Rs-198 strain on alleviating salt stress of cotton. J. Plant Nutr. 2017, 40, 1180-1189. [CrossRef]

189. Vardharajula, S.; Ali, S.Z.; Grover, M.; Reddy, G.; Bandi, V. Drought-tolerant plant growth promoting bacillus spp.: Effect on growth, osmol ytes, and antioxidant status of maize under drought stress. J. Plant Interact. 2011, 6, 1-14. [CrossRef]

190. Liu, S.; Hao, H.; Lu, X.; Zhao, X.; Wang, Y.; Zhang, Y.; Xie, Z.; Wang, R. Transcriptome profiling of genes involved in induced systemic salt tolerance conferred by Bacillus amyloliquefaciens FZB42 in Arabidopsis thaliana. Sci. Rep. 2017, 7, 1-13. [CrossRef]

191. Sangiorgio, D.; Cellini, A.; Donati, I.; Pastore, C.; Onofrietti, C.; Spinelli, F. Facing Climate Change: Application of Microbial Biostimulants to Mitigate Stress in Horticultural Crops. Agronomy 2020, 10, 794. [CrossRef]

192. Suddarth, S.R.P.; Ferreira, J.F.S.; Cavalcante, L.F.; Fraga, V.S.; Anderson, R.G.; Halvorson, J.J.; Bezerra, F.T.C.; Medeiros, S.A.S.; Costa, C.R.G.; Dias, N.S. Can Humic Substances Improve Soil Fertility under Salt Stress and Drought Conditions? J. Environ. Qual. 2019, 48, 1605-1613. [CrossRef]

193. Canellas, L.P.; Olivares, F.L.; Aguiar, N.O.; Jones, D.L.; Nebbioso, A.; Mazzei, P.; Piccolo, A. Humic and fulvic acids as biostimulants in horticulture. Sci. Hortic. 2015, 196, 15-27. [CrossRef]

194. Jindo, K.; Olivares, F.L.; Malcher, D.J.D.P.; Sánchez-Monedero, M.A.; Kempenaar, C.; Canellas, L.P. From Lab to Field: Role of Humic Substances Under Open-Field and Greenhouse Conditions as Biostimulant and Biocontrol Agent. Front. Plant Sci. 2020, 11. [CrossRef]

195. Kaya, C.; Akram, N.; Ashraf, M.; Sonmez, O. Exogenous application of humic acid mitigates salinity stress in maize (Zea mays L.) plants by improving some key physico-biochemical attributes. Cereal Res. Commun. 2018, 46, 67-78. [CrossRef]

196. Beheshti, S.; Tadayyon, A.; Fallah, S. Effect of Humic acid on the yield and yield components of Lima Bean (Phaseolus lunatus L.) under drought stress conditions. Iran. J. Pulses Res. 2017, 7, 175-187.

197. Mahmoudi, M.; Aryaee, P. Study the Effects of Fulvic Acid on Physiological Traits of Citrus Unshu under Salt Stress. Int. J. Chem Envi. Biol. Sci. 2015, 3, 2-4.

198. Lotfi, R.; Gharavi-Kouchebagh, P.; Khoshvaghti, H. Biochemical and physiological responses of Brassica napus plants to humic acid under water stress. Russ. J. Plant Physiol. 2015, 62, 480-486. [CrossRef]

199. Savy, D.; Brostaux, Y.; Cozzolino, V.; Delaplace, P.; Du Jardin, P.; Piccolo, A. Quantitative Structure-Activity Relationship of Humic-Like Biostimulants Derived from Agro-Industrial Byproducts and Energy Crops. Front. Plant Sci. 2020, 11, 11. [CrossRef]

200. Spaccini, R.; Cozzolino, V.; Di Meo, V.; Savy, D.; Drosos, M.; Piccolo, A. Bioactivity of humic substances and water extracts from compost made by ligno-cellulose wastes from biorefinery. Sci. Total. Environ. 2019, 646, 792-800. [CrossRef]

201. Popko, M.; Michalak, I.; Wilk, R.; Gramza, M.; Chojnacka, K.; Górecki, H. Effect of the New Plant Growth Biostimulants Based on Amino Acids on Yield and Grain Quality of Winter Wheat. Molecules 2018, 23, 470. [CrossRef]

202. Abdelhamid, M.T.; Sadak, M.S.; Schmidhalter, U. Effect of Foliar Application of Aminoacids on Plant Yield and Physiological Parameters in Bean Plants Irrigated with Seawater. Acta Biol. Colomb. 2014, 20, 140-152. [CrossRef]

203. Da Silva, M.A.; Cavalcante, I.H.L.; Mudo, L.E.D.; Neto, V.B.D.P.; E Amariz, R.A.; Da Cunha, J.G. Biostimulant alleviates abiotic stress of mango grown in semiarid environment. Rev. Bras. Eng. Agríc. Ambient. 2020, 24, 457-464. [CrossRef]

204. Hammad, S.A.; Ali, O.A. Physiological and biochemical studies on drought tolerance of wheat plants by application of amino acids and yeast extract. Ann. Agric. Sci. 2014, 59, 133-145. [CrossRef]

205. Francesca, S.; Arena, C.; Mele, B.H.; Schettini, C.; Ambrosino, P.; Barone, A.; Rigano, M.M. The Use of a Plant-Based Biostimulant Improves Plant Performances and Fruit Quality in Tomato Plants Grown at Elevated Temperatures. Agronomy 2020, 10, 363. [CrossRef]

206. Jiménez-Arias, D.; García-Machado, F.J.; Morales-Sierra, S.; Luis, J.C.; Suarez, E.; Hernández, M.; Valdés, F.; Borges, A.A. Lettuce plants treated with L-pyroglutamic acid increase yield under water deficit stress. Environ. Exp. Bot. 2019, 158, 215-222. [CrossRef]

207. Moreno-Hernández, J.M.; Benítez-García, I.; Mazorra-Manzano, M.A.; Ramírez-Suárez, J.C.; Sánchez, E. Strategies for production, characterization and application of protein-based biostimulants in agriculture: A review. Chil. J. Agric. Res. 2020, 80, 274-289. [CrossRef]

208. Basile, B.; Rouphael, Y.; Colla, G.; Soppelsa, S.; Andreotti, C. Appraisal of emerging crop management opportunities in fruit trees, grapevines and berry crops facilitated by the application of biostimulants. Sci. Hortic. 2020, 267, 109330. [CrossRef]

209. Kocira, S.; Szparaga, A.; Hara, P.; Treder, K.; Findura, P.; Bartoš, P.; Filip, M. Biochemical and economical effect of application biostimulants containing seaweed extracts and amino acids as an element of agroecological management of bean cultivation. Sci. Rep. 2020, 10, 1-16. [CrossRef] [PubMed]

210. da Silva Rodrigues-Corrêa, K.C.; Fett-Neto, A.G. Abiotic Stresses and Non-Protein Amino Acids in Plants. Crit. Rev. Plant Sci. 2019, 38, 411-430.

211. Matsunami, M.; Toyofuku, K.; Kimura, N.; Ogawa, A. Osmotic Stress Leads to Significant Changes in Rice Root Metabolic Profiles between Tolerant and Sensitive Genotypes. Plants 2020, 9, 1503. [CrossRef]

212. Parthasarathy, A.; Savka, M.A.; Hudson, A.O. The Synthesis and Role of $\beta$-Alanine in Plants. Front. Plant Sci. $2019,10,921$. [CrossRef] 
213. Song, Q.; Joshi, M.; DiPiazza, J.; Joshi, V. Functional Relevance of Citrulline in the Vegetative Tissues of Watermelon During Abiotic Stresses. Front. Plant Sci. 2020, 11, 512. [CrossRef]

214. Janz, D.; Behnke, K.; Schnitzler, J.-P.; Kanawati, B.; Schmitt-Kopplin, P.; Polle, A. Pathway analysis of the transcriptome and metabolome of salt sensitive and tolerant poplar species reveals evolutionary adaption of stress tolerance mechanisms. BMC Plant Biol. 2010, 10, 150. [CrossRef]

215. Campobenedetto, C.; Mannino, G.; Agliassa, C.; Acquadro, A.; Contartese, V.; Garabello, C.; Bertea, C.M. Transcriptome Analyses and Antioxidant Activity Profiling Reveal the Role of a Lignin-Derived Biostimulant Seed Treatment in Enhancing Heat Stress Tolerance in Soybean. Plants 2020, 9, 1308. [CrossRef] [PubMed]

216. Munns, R.; James, R.A.; Sirault, X.R.R.; Furbank, R.T.; Jones, H.G. New phenotyping methods for screening wheat and barley for beneficial responses to water deficit. J. Exp. Bot. 2010, 61, 3499-3507. [CrossRef] [PubMed]

217. Siddiqui, Z.S.; Cho, J.-I.; Kwon, T.-R.; Ahn, B.-O.; Lee, K.-S.; Jeong, M.-J.; Ryu, T.-H.; Lee, S.-K.; Park, S.-C.; Park, S.-H. Physiological mechanism of drought tolerance in transgenic rice plants expressing Capsicum annuum methionine sulfoxide reductase B2 (CaMsrB2) gene. Acta Physiol. Plant. 2014, 36, 1143-1153. [CrossRef]

218. Kim, S.L.; Kim, N.; Lee, H.; Lee, E.; Cheon, K.-S.; Kim, M.; Baek, J.; Choi, I.; Ji, H.; Yoon, I.S.; et al. High-throughput phenotyping platform for analyzing drought tolerance in rice. Planta 2020, 252, 1-18. [CrossRef]

219. Petrie, P.R.; Wang, Y.; Liu, S.; Lam, S.; Whitty, M.A.; Skewes, M.A. The accuracy and utility of a low cost thermal camera and smartphone-based system to assess grapevine water status. Biosyst. Eng. 2019, 179, 126-139. [CrossRef]

220. Nagel, K.A.; Putz, A.; Gilmer, F.; Heinz, K.; Fischbach, A.; Pfeifer, J.; Faget, M.; Blossfeld, S.; Ernst, M.; Dimaki, C.; et al. GROWSCREEN-Rhizo is a novel phenotyping robot enabling simultaneous measurements of root and shoot growth for plants grown in soil-filled rhizotrons. Funct. Plant Biol. 2012, 39, 891-904. [CrossRef] [PubMed]

221. Xu, W.; Cui, K.; Xu, A.; Nie, L.; Huang, J.; Peng, S. Drought stress condition increases root to shoot ratio via alteration of carbohydrate partitioning and enzymatic activity in rice seedlings. Acta Physiol. Plant. 2015, 37, 9. [CrossRef]

222. Rouphael, Y.; Spíchal, L.; Panzarová, K.; Casa, R.; Colla, G. High-Throughput Plant Phenotyping for Developing Novel Biostimulants: From Lab to Field or From Field to Lab? Front. Plant Sci. 2018, 9, 1197. [CrossRef] [PubMed] 